\title{
Characterization and Evolutionary Analysis of a Large Polygalacturonase Gene Family in the Oomycete Plant Pathogen Phytophthora cinnamomi
}

\author{
Arvid Götesson, Jerry S. Marshall, David A. Jones, and Adrienne R. Hardham \\ Plant Cell Biology Group, Research School of Biological Sciences, Australian National University, Canberra ACT 2601, \\ Australia
}

Submitted 28 December 2001. Accepted 3 May 2002.

Polygalacturonases (PGs) are secreted by fungal pathogens during saprophytic and parasitic growth, and their degradation of pectin in the plant cell wall is believed to play a major role in tissue invasion and maceration. In this study, PG activity was demonstrated in culture filtrates of the oomycete plant pathogen, Phytophthora cinnamomi. A P . cinnamomi pg gene fragment amplified using degenerate primers based on conserved regions in fungal and plant PGs was used to isolate 17 complete $P$. cinnamomi $p$ genes and pseudogenes from a genomic library and partial sequence for another two genes. Gel blotting of genomic DNA indicated that there may be even more $p g$ genes in the $P$. cinnamomi genome. $P$. cinnamomi $p g$ gene sequences were expressed in PG-deficient yeast and found to confer PG activity, thereby confirming their functional identity. The predicted mature $P$. cinnamomi PGs fall into subgroups that exhibit large differences in the extent of $\mathrm{N}$-glycosylation, isoelectric points, and $\mathrm{N}$ - and $\mathrm{C}$-terminal structure. Evidence for birth-and-death and reticulate evolution in the $P$. cinnamomi $p g$ gene family was obtained, and some codons for surface exposed residues in the $P$. cinnamomi PGs were shown to have been subject to diversifying selection. Contrary to accepted phylogenies for other proteins, phylogenetic analysis of the $P$. cinnamomi PGs revealed a closer relationship with PGs from true fungi than with those from plants.

Plant cell walls are a key factor in plant-pathogen interactions. They can constitute barriers to penetration and colonization by the pathogen, and they are also involved in defense responses of the host plant (Esquerré-Tugayé et al. 2000). In the primary cell wall, cellulose microfibrils are noncovalently bound to hemicelluloses, and the cellulose-hemicellulose network is embedded in a pectin gel (Carpita and Gibeaut 1993). Pectin is also the main component of the middle lamella, which holds neighboring plant cells together. Filamentous plant pathogens penetrate host cell walls through enzymatic action and mechanical pressure (Mendgen and Deising 1993). Most research on cell wall-degrading enzymes (CWDE) produced by fungal pathogens has concentrated on pectinases (Annis and Goodwin 1997). Enzymatic depolymerization of pectin weakens the cell wall, exposes other cell wall components to degradative enzymes, and provides a carbon source for the pathogen. Pectinases are the only CWDE capable of tissue

Corresponding author: A. R. Hardham; E-mail: hardham@rsbs.anu.edu.au; Telephone: +61-2-61254168; Fax +61-2-61254331. maceration by disrupting the middle lamella and are often the first CWDE secreted by invading plant pathogenic fungi (Cooper 1983).

Endopolygalacturonases (endoPGs; EC 3.2.1.15) and exoPGs (EC 3.2.1.67) are pectinases that degrade the galacturonan backbone of pectin molecules. ExoPGs release monomers in a processive fashion from the nonreducing end of the substrate polymer, whereas endoPGs cleave the polygalacturonan backbone of the pectin molecule internally. Some endoPGs are hardly processive, while others have a high likelihood of releasing monomers in a processive fashion from the reducing end of the degradation product after the initial attack. These latter PGs are sometimes referred to as endo/exoPGs.

Plant polygalacturonase-inhibiting proteins (PGIPs) are present in the cell walls of many host plants (Darvill et al. 1994) and are effective against some fungal PGs (Cook et al. 1999; Desiderio et al. 1997; Sharrock and Labavitch 1994; Stotz et al. 1994) but ineffective against bacterial or plant PGs (Cervone et al. 1990). The differential inhibition of PGs by various PGIPs and evidence for adaptive evolution of PGIPs and PGs have been suggested to reflect an evolutionary arms race between PGIPs and PGs in coevolving hosts and pathogens (Stotz et al. 2000). PGIPs may also increase the half-life of oligogalacturonides that elicit plant defenses (Cervone et al. 1989).

Gene inactivation experiments have shown in several cases that pectinases are virulence factors for plant pathogenic fungi. The combined disruption of two pectate lyase genes in Nectria haematococca reduced virulence, although disruption of either gene alone did not (Rogers et al. 2000). The endoPG encoded by pecA in Aspergillus flavus contributes to invasion and spread of the pathogen in cotton bolls (Shieh et al. 1997), and the endoPG gene Bcpg 1 of Botrytis cinerea is required for full virulence, although mutants remain pathogenic (ten Have et al. 1998). In other experiments, pectinase gene inactivation failed to show a requirement for pectinases in pathogenesis, but the activity of enzymes encoded by nondisrupted pectinase genes is presumed to be sufficient for wild-type virulence in these cases (Bowen et al. 1995; Gao et al. 1996; García-Maceira et al. 2000; Scott-Craig et al. 1998).

Our understanding of the role of PGs and other aspects of the biochemistry and molecular biology of plant invasion by filamentous pathogens is based on studies of a small number of true fungi. The oomycetes are another group of filamentous plant pathogens that have a funguslike lifestyle but distinct phylogenetic affinities (Sogin and Silberman 1998). Oomycetes are responsible for many serious plant diseases. Members of one oomycete genus include Phytophthora infestans, which 
causes late blight of potato, and $P$. cinnamomi, which causes extensive losses in agriculture and widespread degradation in natural plant communities (Schumann 1991). Knowledge of the molecular mechanisms underlying Phytophthora species growth and pathogenicity is limited and is not in proportion to the economic and ecological importance of this group of pathogens.

There are some indications that PG activity is a pathogenicity factor in Phytophthora species required for host invasion and perhaps in the production of nutrients (Sanchez et al. 1994). Little is known, however, about the genes that encode Phytophthora PG enzymes apart from the recent isolation of a $P$. infestans cDNA clone encoding a $p g$ gene (Torto et al. 2002), and nothing is known of the possible inhibition of oomycete PGs by plant PGIPs. In order to advance the understanding of the molecular biology of Phytophthora species growth and pathogenicity, we have isolated and characterized a significant portion of a large family of PG-encoding genes from $P$. cinnamomi.

\section{RESULTS}

Detection of PG activity in $P$. cinnamomi culture filtrates.

PG activity in $P$. cinnamomi culture filtrate precipitates was demonstrated using ruthenium red gel staining to detect degradation of the substrate polygalacturonate and the complementary 2-cyanoacetamide assay to detect production of reducing groups. In the 2-cyanoacetamide assay, an average of $0.22 \pm$ $0.02 \mu \mathrm{mol}$ reducing groups per minute per mg of total protein was produced (data not shown).

\section{Isolation and sequencing of $\boldsymbol{P}$. cinnamomi $\mathrm{pg}$ genes.}

Degenerate oligonucleotide primers were designed using conserved regions of reported fungal and plant endoPG genes. A polymerase chain reaction (PCR) amplification product of the expected length was sequenced using the degenerate primers, and a database search confirmed that it was homologous to fungal and plant PG genes.

A radiolabeled probe was made from the $P$. cinnamomi $p g$ PCR product and used to screen a $P$. cinnamomi genomic library in $\lambda E M B L 3$. In the first round of screening, 60 positive plaques were detected. From 13 purified genomic clones, des- ignated GC1, GC3 to GC7, GC9 to GC11, GC33, GC37, GC52, and GC60, 19 Pcpg gene sequences designated Pcpg1 to Pcpg19 were identified and sequenced, and the sequences were submitted to GenBank (accession numbers AF398105, AF398936 to AF398948). Seventeen complete genes were isolated. Three of these sequences appeared to be pseudogenes: Pcpg5 contained an internal stop codon, Pcpg 18 contained a frameshift mutation, and Pcpg13 was truncated and lacked the 5 ' coding region (Table 1). Otherwise, these three genes were similar to structurally normal Pcpg genes and the putative inactivating mutations might therefore be recent. The $5^{\prime}$ coding and upstream regions of the two remaining genes, Pcpgll and Pcpg17, were not recovered in the genomic clones analyzed.

In a gel blot of SalI-digested $P$. cinnamomi genomic DNA probed with Pcpg1, 18 bands were observed (data not shown). The 13 genomic clones analyzed contained a total of $10 \mathrm{com}-$ plete and 4 incomplete genomic SalI fragments that hybridized with the Pcpg1 probe. This means that at least four genomic SalI fragments that hybridize with Pcpgl have not been isolated. The fact that only a single clone was isolated for 8 of the 19 P. cinnamomi pg genes also indicates, on statistical grounds, that the $P$. cinnamomi genomic library has not been sampled completely.

\section{Genomic organization of the Pcpg multigene family.}

Pcpg1 to Pcpg13 were organized in three clusters (Fig. 1A). The physical location within the $P$. cinnamomi genome of these three clusters relative to one another or to the other six genes sequenced (Pcpg14 to Pcpg19) is not known. A 12-kb contig of subclones derived from overlapping genomic clones 7 and 37 containing cluster I (PcpgI to Pcpg6) was sequenced completely. The genomic clones containing clusters II (Pcpg7 to Pcpg11) and III (Pcpg12 and Pcpg13) were sequenced only to the extent necessary to determine the sequence, order, and orientation of the $p g$ genes. Cluster I had a higher density of $p g$ genes than clusters II and III (Fig 1A). Although the intergenic regions in clusters II and III were not sequenced completely, no sequence was found to indicate that other genes were interspersed among the $p g$ genes.

In three instances (Pcpg2 and Pcpg3, Pcpg7 and Pcpg8, and Pcpg12 and the truncated Pcpg13), pairs of adjacent genes

Table 1. Theoretical pI values and structural features of the Phytophthora cinnamomi polygalacturonases

\begin{tabular}{|c|c|c|c|c|c|c|}
\hline & \multicolumn{2}{|c|}{ Theoretical pI value } & \multirow[b]{2}{*}{$\begin{array}{l}\text { Repeat sequence in } \\
\text { N-terminal extension }\end{array}$} & \multirow[b]{2}{*}{$\begin{array}{c}\text { C-terminal } \\
\text { disulphide bridge }\end{array}$} & \multirow[b]{2}{*}{$\begin{array}{l}\text { Potentially highly } \\
\text { glycosylated }\end{array}$} & \multirow[b]{2}{*}{$\begin{array}{c}\text { Probably } \\
\text { nonfunctional }^{\mathrm{a}}\end{array}$} \\
\hline & $\begin{array}{c}\text { Including N-terminal } \\
\text { extension }\end{array}$ & $\begin{array}{c}\text { Excluding N-terminal } \\
\text { extension }\end{array}$ & & & & \\
\hline PcPG1 & $\mathrm{NA}^{\mathrm{b}}$ & $5.1 * \mathrm{c}$ & NA & + & No & No \\
\hline PcPG2 & NA & $9.2^{*}$ & NA & + & No & No \\
\hline PcPG3 & NA & $9.2 *$ & NA & + & No & No \\
\hline PcPG4 & NA & $4.0^{*}$ & NA & + & No & No \\
\hline PcPG5 & NA & $4.7 *$ & NA & + & No & Yes \\
\hline PcPG6 & NA & $5.1 *$ & NA & + & No & No \\
\hline PcPG7 & $8.6^{*}$ & 9.3 & D(P/Q)TQQQ & - & No & No \\
\hline PcPG8 & $6.8^{*}$ & 8.8 & $\mathrm{D}(\mathrm{P} / \mathrm{Q}) \mathrm{TQQQ}$ & - & No & No \\
\hline PcPG9 & $6.9 *$ & 7.0 & D(P/Q)TQQQ & - & No & No \\
\hline PcPG10 & $7.0 *$ & 8.8 & $\mathrm{D}(\mathrm{P} / \mathrm{Q}) \mathrm{TQQQ}$ & - & No & No \\
\hline PcPG11 & NA & NA & Not retrieved & + & No & No \\
\hline PcPG12 & 5.1 & $7.7 *$ & NPGQN & + & Yes & No \\
\hline PcPG13 & NA & NA & Truncated & + & Yes & Yes \\
\hline PcPG14 & 5.0 & $7.7 *$ & NPGQN & + & Yes & No \\
\hline PcPG15 & 5.1 & $8.1^{*}$ & NPGQN & + & Yes & Yes \\
\hline PcPG16 & $6.2 *$ & 6.5 & NPGQN & + & Yes & No \\
\hline PcPG17 & $8.8^{*}$ & 8.7 & NPGQN & + & Yes & No \\
\hline PcPG18 & $7.7 *$ & 8.6 & NPGQN & + & Yes & Yes \\
\hline PcPG19 & $6.8^{*}$ & 8.5 & $\mathrm{D}(\mathrm{P} / \mathrm{Q}) \mathrm{TQQQ}$ & - & No & No \\
\hline
\end{tabular}


were greater than $97 \%$ identical. The tandemly repeated genes Pcpg12 and Pcpg13 were also greater than $99 \%$ identical to Pcpg14 and Pcpg15, respectively, and Pcpg17 and Pcpg18 were $93 \%$ identical to each other. Given that physically linked $P$. cinnamomi $p g$ genes were in several instances very similar and that some of the physically linked genes were organized in widely spaced clusters (Fig. 1A), it is possible that Pcpg14 and Pcpg15 formed part of gene cluster III and that Pcpg17 and Pcpg18 were clustered, even though these four genes were recovered as single gene clones. Alternatively, since $P$. cinnamomi is a diploid organism, Pcpg17 and Pcpg18 may be alleles, and similarly, Pcpg14 and Pcpg 15 may be allelic to each other or to Pcpg12 or Pcpg13.

The sequences flanking these genes were examined to see if any further insight could be gained about their physical relationships. The downstream flanking regions of Pcpg17 and Pcpg18 were dissimilar (Fig. 1B), suggesting that they are unlikely to be alleles. The sequences downstream of Pcpg12 and Pcpg 14 were almost identical, as were those downstream of Pcpg13 and Pcpg15, but these two pairs of downstream regions were distinct from one another (Fig. 1C). A gene encoding a protein of unknown function, homologous to one found in several other organisms, including Arabidopsis thaliana (accession number AAD41975), was found downstream of Pcpg13 and Pcpg15 (Fig. 1C). Taken alone, these data would suggest that Pcpg12 might be allelic to Pcpg14 and that Pcpg13 might be allelic to Pcpg15. Pcpg14 and Pcpg15 might, therefore, be physically linked members of a complex locus allelic to the complex locus carrying Pcpg12 and Pcpg13. However, in the region immediately upstream of the start codon, Pcpg12, Pcpg14, and Pcpg15 had 224 bp of almost identical sequence, but extended similarity was evident only between Pcpg14 and Pcpg15 (Fig. 1C). Given that the 5' coding region of Pcpgl3 has been deleted (Fig. 1C), it is possible that the intergenic region between Pcpg12 and Pcpg13, which encompasses their upstream flanking regions, has been altered extensively by sequence rearrangement, making a definitive conclusion regarding possible allelism difficult.

A short (56 to $88 \mathrm{bp}$ ) intron in a conserved position was predicted in nine of the $P$. cinnamomi $p g$ sequences by the presence of consensus splice donor and acceptor sites (Fig. 2). The incomplete Pcpg17 sequence and the structurally similar pseudogene Pcpg 18 both contained an additional intron at identical positions. The upstream regions of the $P$. cinnamomi pg genes contained a motif (GCTCATTYYNCAWTTT) that is also present at the transcription start points of a number of oomycete genes whose transcription start points have been determined (Pieterse et al. 1994). Putative polyadenylation signals (AATAAA) were found downstream of the stop codon in Pcpg8, Pcpg9, Pcpg10, Pcpg12, and Pcpg14. It was not possible to identify polyadenylation signals in the other genes.

\section{Analysis of deduced amino acid sequences.}

Amino acid sequences were deduced from the predicted open reading frames. The predicted unprocessed proteins varied in length from 361 to 454 amino acid residues (Fig. 2); the variation in length being due to $\mathrm{N}$-terminal extensions ranging from approximately 15 to 92 amino acid residues in length (Fig. 3).

PGs have four highly conserved domains in the catalytic site and seven amino acid residues within these domains are strictly conserved in all reported PGs. Numbered according to their positions in PcPG4, these residues are $\mathrm{N}^{178} \mathrm{XD}^{180}$, $\mathrm{D}^{201} \mathrm{D}^{202}, \mathrm{H}^{223} \mathrm{G}^{224}$, and $\mathrm{K}^{261} \cdot \mathrm{R}^{259}$ is also conserved in all PGs except insect PGs, which have a conservative substitution to $\mathrm{H}$ at this site. These eight residues were conserved in all $P$. cinnamomi PGs except PcPG15 which had $\mathrm{D}^{291} \mathrm{~A}^{292}$ instead of
$\mathrm{D}^{291} \mathrm{D}^{292}$ in the second conserved region. The $P$. cinnamomi PGs also have two conserved residues adjacent to the active site, exemplified by PcPG4 $\mathrm{D}^{183}$ (equivalent to Aspergillus niger PGII $\mathrm{D}^{183}$ ), which is conserved in all fungal PGs, and by $\mathrm{Y}^{293}$ (equivalent to A. niger PGII $\mathrm{Y}^{291}$ ), which is conserved in all PGs. These residues have been shown to be involved in substrate binding in A. niger PGII (Pagès et al. 2000).

All of the complete P. cinnamomi PGs contained a signal peptide predicted according to the method of Nielsen and associates (1997) (Fig. 2). Putative monobasic (arginine) propeptide cleavage sites were present in all of the complete $P$. cinnamomi PGs except the hypothetical amino acid sequence corresponding to the pseudogene $P \operatorname{cpg} 18$, which contained a dibasic (arginine-arginine) site (Figs. 2 and 3), suggesting possible similarity to dibasic propeptide cleavage sites found in some fungal PGs. A consensus sequence consisting of proline at position -4 , amino acids with aliphatic side chains or methionine

A

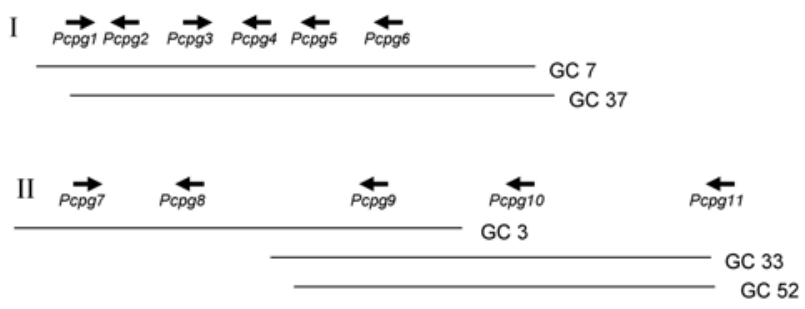

III

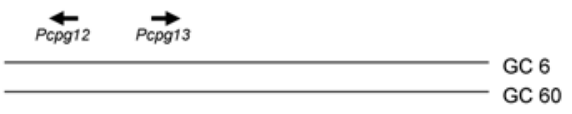

$\overline{1 \mathrm{~kb}}$

B

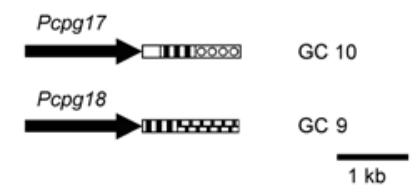

C

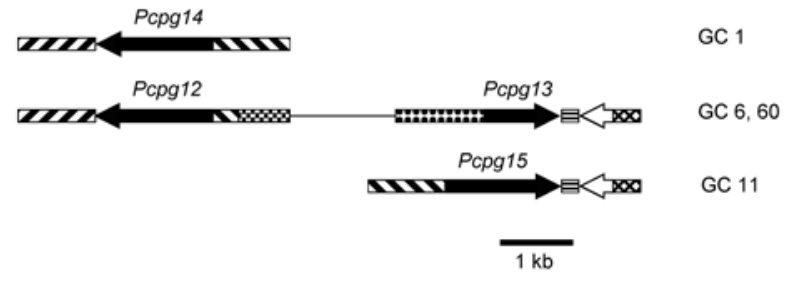

Fig. 1. Phytophthora cinnamomi polygalacturonase gene clusters. A, $P$. cinnamomi polygalacturonase $(P c p g)$ genes 1 to 13 were organized in three clusters (I to III). The genomic clones (GCs) from which the genes were isolated are depicted below black arrows representing the relative location of the Pcpg genes and indicating their direction of transcription. The 5' region of Pcpg11 was not contained within the genomic clones. Pcpg 13 was a truncated gene that lacked the 5 ' coding regions. B, Downstream regions of Pcpg17 and Pcpg18. Patterns indicate sequence similarity. C, Sequenced portions of GC 1, GCs 6 and 60 and GC 11 showing the sequence context of genes Pcpg12 to Pcpg14. Patterns indicate sequence identity. DNA gel blotting showed that the region between Pcpg12 and Pcpg13 that was not sequenced (thin line) did not contain $p g$ coding sequence. The truncated Pcpg13 gene is flanked on the $5^{\prime}$ side by sequence not found in the upstream regions of Pcpg12, Pcpg14, and $P c p g 15$. White arrows indicate a gene of unknown function. 
at positions -3 and -2 , and an arginine at position -1 relative to the potential cleavage site was observed (Fig. 3).

In PcPG7 to PcPG10 and PcPG19 this consensus sequence was found upstream of the N-terminal extension (Fig. 3), suggesting retention of the $\mathrm{N}$-terminal extension in the mature proteins, as is the case with A. niger PGD, a fungal PG with an $\mathrm{N}$ terminal extension (Pařenicová et al. 2000b). In PcPG12 and PcPG14 to PcPG18, the consensus occurs downstream of the extension (Fig. 3), but in PcPG16, the conserved arginine is replaced with glutamic acid and in PcPG17 and PcPG18, by ly- sine. This suggests that the N-terminal extensions may be lost in PcPG12, PcPG14, and PcPG15, but may be retained in PcPG16 to PcPG18, unless the lysine residues in PcPG17 and PcPG18 function in monobasic cleavage. PcPG16 to PcPG18 have nonconsensus arginine residues located upstream of the $\mathrm{N}$-terminal extension that might act as alternative propeptide cleavage sites, although some of these may be too close to the predicted signal peptide cleavage sites to enable the $P$. cinnamomi maturase to engage these PcPGs (Fig. 3). PcPG16 also has a nonconsensus arginine residue just upstream of the mu-

pre mat

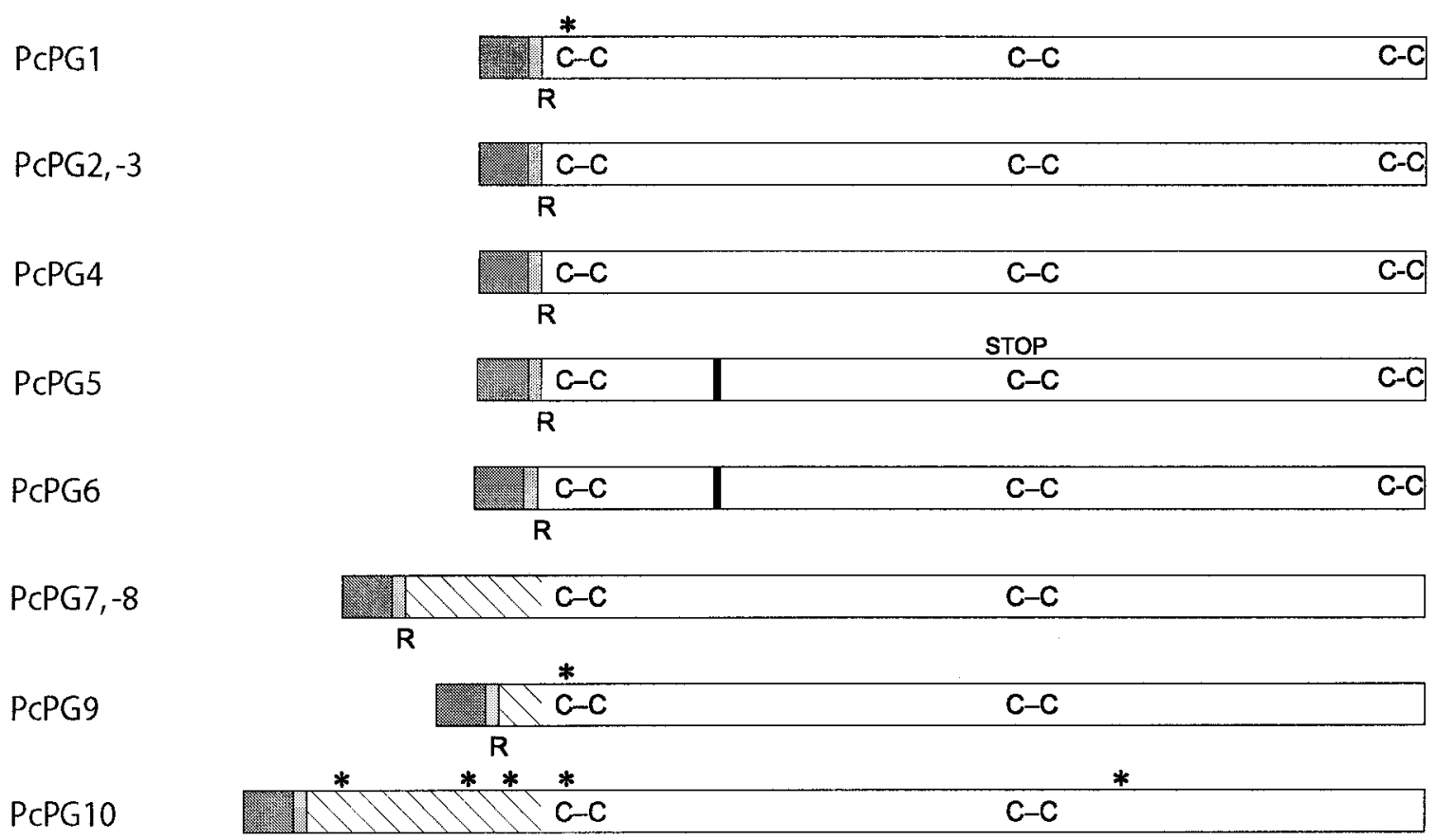

361.336

361336

361336

NA NA

454429

R

PCPG11
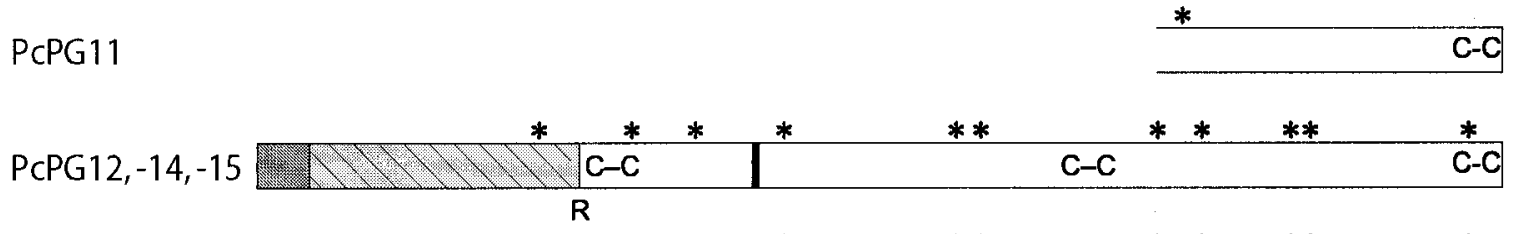

452331

PCPG13

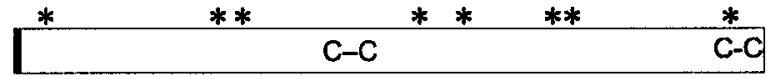

NA NA

PCPG16

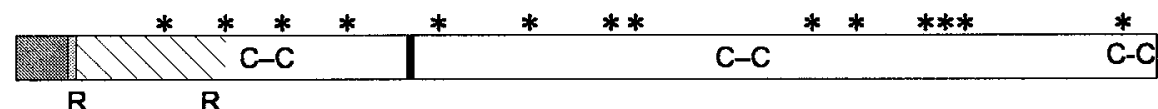

PCPG17

$\begin{array}{ll}R & R\end{array}$

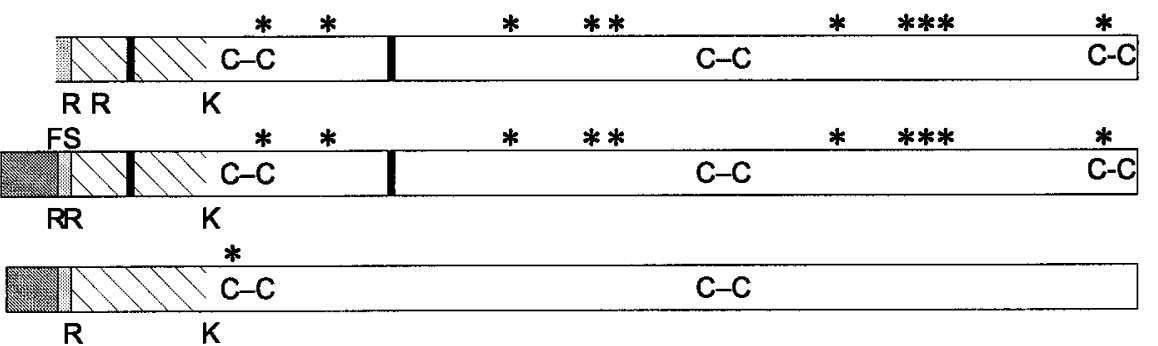

NA NA

PCPG19

$$
\text { R }
$$

$\mathrm{K}$

406381

Fig. 2. Structure of the Phytophthora cinnamomi polygalacturonase proteins. Predicted introns (I), nonsense (STOP), and frameshift (FS) mutations in the original DNA sequence, length of unprocessed protein in amino acids (pre), length of mature protein (mat), signal peptides (dark grey), N-terminal extensions (hatched), conserved cysteines (C), potential $N$-glycosylation sites $(*)$, predicted monobasic propeptide cleavage sites (R or K) and predicted propeptides (light grey) are indicated. A dibasic site (RR) was found in PcPG18. Predicted signal peptides were 20-amino acid residues long, except the signal peptides of PcPG12, PcPG14 to PcPG16, and PcPG18, which were 22 residues long. The 5 ' region of Pcpg11 and the region of $P c p g 17$ encoding the signal peptide of PcPG17 were not retrieved. Protein structures corresponding to presumably non-functional Pcpg5, Pcpg13, Pcpg15, and Pcpg18 are included for comparison purposes. 
tated consensus sequence. If the $P$. cinnamomi maturase is able to cleave at this position, it would remove most of the N-terminal extension (Fig. 3).

Apart from the N-terminal extensions, the P. cinnamomi PGs were structurally similar. Except for proteins encoded by almost identical genes (PcPG2 and PcPG3, PcPG7 and PcPG8, and PcPG12 to PcPG15), pairwise sequence identity varied between 55 and $89 \%$. The N-terminal extensions, on the other hand, were divided into two almost unrelated subgroups (Fig. 3 , Table 1). The central region of the extension of PcPG10 contained glutamine-rich repeats (DQTQQQ), and downstream of these repeats, PcPG10 had a serine- and threonine-rich sequence. The extensions of PcPG7, PcPG8, PcPG9, and PcPG19 were similar to the extension of PcPG10, but contained large gaps compared to PcPG10. The extensions of the second subgroup, PcPG12 and PcPG14 to PcPG18, contained a different repeat (NPGQN) (Fig. 3, Table 1).

There was also a striking division of the $P$. cinnamomi PGs into two subgroups based on the number of potential $N$-glycosylation sites. PcPG1 to PcPG10, PcPG19, and the known part of PcPG11 contained no or few $N$-glycosylation sites, whereas PcPG12 and PcPG14 to PcPG18 carried 10 to $14 \mathrm{~N}$-glycosylation sites, 8 of them conserved (Fig. 2, Table 1). The truncated Pcpgl3 gene encoded six of these conserved sites.

All P. cinnamomi PGs, except the partially recovered PcPG11 and the truncated PcPG13, had two conserved cysteines at the $\mathrm{N}$-terminus, and all had two conserved cysteines in the central region (Fig. 2). PcPG1 to PcPG6 and PcPG11 to PcPG18 also had two more conserved cysteines at the C-terminus. Five of the six $P$. cinnamomi PGs characterized by few glycosylation sites and extensions containing glutamine-rich repeats lacked both of these cysteines and showed divergent $\mathrm{C}$ terminal sequences compared to the other $P$. cinnamomi $\mathrm{PGs}$ (Fig. 2, Table 1).

The $\mathrm{pI}$ values of the inferred mature proteins, predicted using the method of Bjellqvist and associates (1993), varied between 4.0 and 9.2, the majority having neutral or slightly basic pI values (6.8 to 8.8 ) (Table 1). The distribution of $\mathrm{pI}$ values did not follow the division of the PGs into classes observed in the analysis of $\mathrm{N}$-terminal structure and $\mathrm{N}$-glycosylation pattern or the physical clustering. For example, the PcPGs with the highest and lowest predicted pI were encoded by the adjacent Pcpg3 and Pcpg4 genes in cluster I.

\section{Functional analysis of $P$. cinnamomi PGs.}

Pcpg genes were expressed in yeast and were shown to confer PG activity, confirming their functional identity as polygalacturonase genes. Preliminary experiments using reverse transcription (RT)-PCR detected expression of Pcpg genes in vitro and in planta. A detailed study of the activity and biochemical properties of yeast-expressed PcPGs and a detailed analysis of Pcpg gene expression patterns are currently underway.

\section{Phylogenetic analysis.}

A phylogenetic tree based on an alignment of the $P$. cinnamomi PGs that excluded the variable $\mathrm{N}$-terminal extensions was constructed (Fig. 4). Phylogenetically, the P. cinnamomi PGs fall into three clusters that correlate with the physical clustering (Fig. 1) and with the separation into different classes found in the analysis of glycosylation patterns and $\mathrm{N}$ - and $\mathrm{C}$ terminal structure (Fig. 2). A phylogenetic analysis of the relationship between the $P$. cinnamomi PGs and the $P$. infestans PG PiPG1 (Torto et al. 2002) showed that PiPG1 is most homologous to the subgroup PcPG12 to PcPG18.

A multiple sequence alignment was made using reported PG sequences from bacteria, fungi, insects and plants, and five $P$. cinnamomi PGs representing the subgroups discernible in the $P$. cinnamomi PG phylogeny (Fig. 4). Sequences were chosen so that the monophyletic groups identified in the plant PG (Torki et al. 2000) and fungal endoPG (Wubben et al. 1999) phylogenies were represented and $\mathrm{N}$ - and $\mathrm{C}$-terminal extensions were excluded. An unrooted phylogenetic tree was obtained that positioned the $P$. cinnamomi PGs closer to fungal and insect endoPGs than to plant and bacterial PGs or fungal exoPGs (Fig. 5).

\section{Reticulate evolution.}

Homologous genes often exchange genetic information by recombination or gene conversion leading to a patchwork of shared sequence polymorphisms between different members of a gene family. This phenomenon has been termed reticulate evolution. Analysis of shared polymorphisms in the Pcpg genes using Sawyer's runs test implemented in GENECONV 1.81 (discussed below) provided strong support for reticulate evolution in some Pcpg genes. In 10 instances, stretches of polymorphisms shared by pairs of $P c p g$ genes had global $P$ values (discussed below) of less than 0.05 , and 31 such fragments had pairwise $P$ values less than 0.01 . Randomized data (10 sample DNA alignments arising from permutation of the polymorphic sites) yielded no fragments with global $P$ values less than 0.05 and, in no case, more than four fragments with pairwise $P$ values less than 0.01 .

Two genes in cluster I have undoubtedly been affected by reticulate evolution. A 473-bp-long fragment in Pcpg4 (positions 331 to 803 in the analyzed $P$ cpg gene alignment) had an almost exact match in Pcpg 5 (global $P$ value of less than 0.0001 ), while the flanking regions were only moderately similar. Two shorter fragments (positions 431 to 578 in Pcpg1 and Pcpg2 and positions 419 to 560 in Pcpg7 and Pcpg10) had global $P$ values of less than 0.001 . It is also highly likely that a gene conversion or

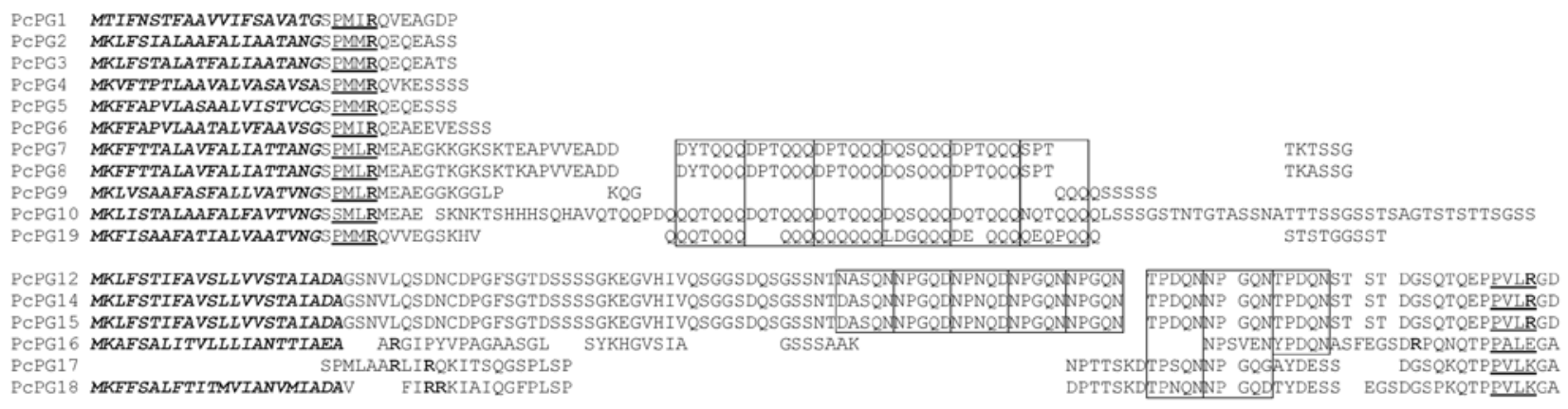

Fig. 3. Alignment showing the N-terminal regions of the Phytophthora cinnamomi polygalacturonases. Regions of the unprocessed proteins upstream of the first conserved cysteine residue are shown. Predicted signal peptides are indicated in bold and italics. The consensus sequence preceding putative propeptide cleavage sites is underlined and arginine residues are in bold. Repeats are indicated with boxes. 
recombination event has affected the $3^{\prime}$ regions of Pcpg16 and the ancestor of Pcpg17 and Pcpg18; the global $P$ value was less than 0.005 for positions 541 to 990 in Pcpg16 and Pcpg18 and was less than 0.01 for a slightly shorter fragment shared by Pcpg16 and Pcpg17 (positions 598 to 929).

The remaining probable instances of reticulate evolution detected by Sawyer's runs test were also intracluster events or events involving genes that were closely related in all regions and therefore possibly clustered in the genome. Intercluster exchange of genetic information between more divergent genes may be less frequent and such events may have become obscured by subsequent more frequent intracluster sequence exchange and other mutations and therefore more difficult to detect using the runs test, which requires pairwise fragments with relatively few mismatches. In order to detect more subtle evidence for reticulate evolution, patterns of shared parsimoniously informative sites in the Pcpg gene alignment were explored by generating phylogenetic profiles using PhylPro (discussed below). The phylogenetic profiles for the alignment with no genes excluded are shown in Figure 6A. Several instances of strong recombination signals indicate that reticulate evolution has contributed to the evolution of the P. cinnamomi gene family. Putative recombinant sequences were identified by excluding sequences from the alignment until the alignment contained only one sequence that had a distinct minimum, or minima, in its phylogenetic profile, at least in the region in which one or more strong recombination signals occurred. The other sequences in the alignment presumably reflected the an-

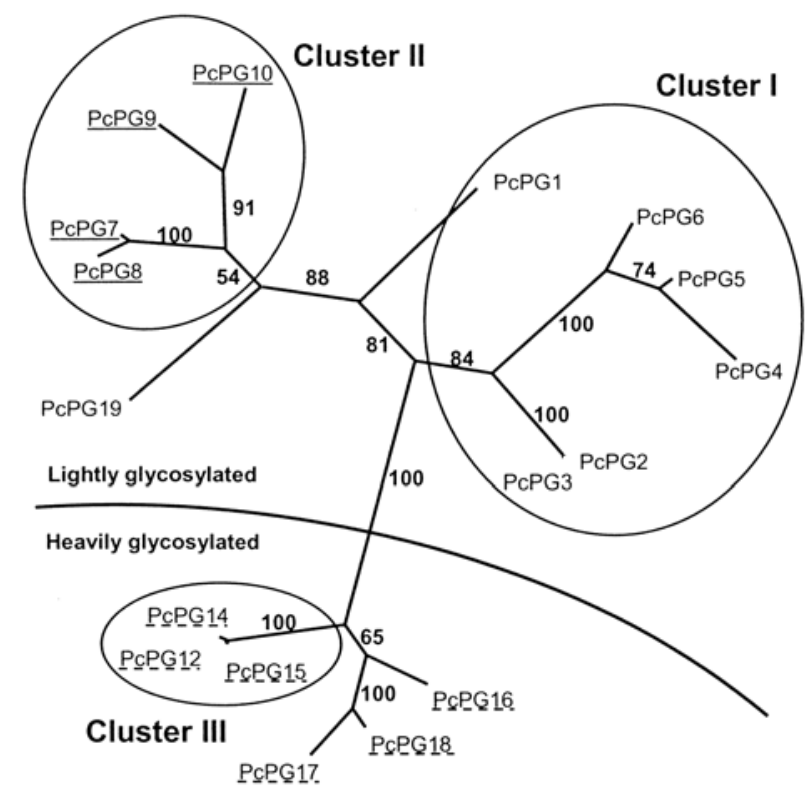

-10 changes

Fig. 4. Phylogenetic tree of the Phytophthora cinnamomi polygalacturonases. All of the PcPGs except the truncated PcPG13 and the incomplete PcPG11 were included in the analysis. Putative signal peptides, propeptides, and $\mathrm{N}$-terminal extensions were excluded from the protein sequence alignment. The recovered part of PcPG11 was most similar to the C-terminal regions of PcPG9 and PcPG10. Ellipses indicate physical clustering in the genome. PcPG14 and PcPG15 are shown as part of cluster III, since they are probably allelic or physically linked to PcPG12 and PcPG13. Proteins with N-terminal extensions containing glutamine-rich repeats (underlined with solid lines) and extensions containing the repeat NPGQN (underlined with broken lines), as well as proteins with heavy and light potential glycosylation patterns, are indicated. Bootstrap support values are indicated where bootstrap support for branches was $\geq 50$. cestral sequences of the recombinant, at least in that region of the gene.

Strong recombination signals appeared in the phylogenetic profile of Pcpg6 when compared with its close relatives in cluster I (Pcpg4 and Pcpg5) and to the more distantly related Pcpg9 and Pcpg10 in cluster II (Fig. 6B). The region between the signals at positions 410 and 510 in Figure $6 \mathrm{~B}$ contained fragments shared by Pcpg6 and the genes in cluster II. Since PhylPro does not enable tests of significance to be carried out, Pcpg6 and two genes representing the probable parental lineages (Pcpg5 and Pcpg10) were analyzed using the maximum chisquared method (Maynard Smith 1993), which identifies the most probable breakpoints and estimates the probability that the alignment has a mosaic structure. The breakpoints in Pcpg6 identified using PhylPro were also identified by the maximum chi-squared method, and the mosaic structure of Pcpg6 was statistically significant $(P<0.0001$ for the upstream breakpoint and $P<0.0005$ for the downstream breakpoint).

The same set of phylogenetic profiles (Fig. 6B) also suggested the presence of two recombination breakpoints in Pcpg4, indicated by the two signals at positions 52 and 190. A comparison of Pcpg4 with Pcpg6 and Pcpg10 using the maximum chi-squared method indicated that Pcpg4 may also have been affected by reticulate evolution involving clusters I and II, but the support was considerably weaker $(P<0.05)$.

Strong recombination signals also appeared at positions 633 and 798 in the phylogenetic profile of Pcpg2 when compared with Pcpg4 and Pcpg5 in cluster I and with the more distantly related Pcpg12 and Pcpg14 in cluster III (Fig. 6C). Phylogenetic trees generated using parsimony showed that in the regions 1 to 632 and 799 to 990 of the DNA alignment, Pcpg2 was closely related to Pcpg4 to Pcpg6 (data not shown). Trees for the region 633 to 798 suggested that $P c p g 2$ was related to Pcpg12 to Pcpg18 (data not shown), but the bootstrap support was not significant. Pcpg2 and genes representing the putative parental lineages were also analyzed using the maximum chisquared method. The breakpoints shown in Figure 6C were detected, but they were not statistically significant.

Significance tests for recombination in Pcpg2 conducted using phylogenetic trees or the maximum chi-squared method relied on the assumption that single clearcut recombination breakpoints had been detected. Detailed inspection of informative sites in an alignment comprising Pcpg2, Pcpg4, Pcpg5, Pcpg12, and Pcpg14 confirmed that Pcpg2 in some regions was closely related to genes in cluster III but that distinct boundaries between blocks with conflicting phylogenies were difficult to locate (Fig. 7). Therefore, Pcpg2 and genes representing the putative parental lineages were analyzed using SiScan (discussed below), which provides a measure of the relatedness signals in different parts of the alignment and tests the significance of the signals without attempting to locate breakpoints. An analysis of Pcpg2, Pcpg5, and Pcpg12 (Fig. 8) showed the presence of regions in $P c p g 2$ significantly similar to Pcpg12 ( $Z$ score $>3)$, and the highest scores were obtained in the region between the strongest recombination signals detected by PhylPro (Fig. 6C).

Additional putative recombination events were detected using PhylPro, but the conflicting phylogenetic signals suggested by the patterns of shared informative sites were, in these cases, not significantly strong according to the described tests. However, the instances of reticulate evolution detected using Sawyer's runs test were also detected using PhylPro and were shown to be significant using the maximum chi-squared method.

\section{Identification of sites undergoing diversifying selection.}

Comparison of nonsynonymous or amino acid replacing $\left(\mathrm{K}_{\mathrm{a}}\right)$ and synonymous or silent $\left(\mathrm{K}_{\mathrm{s}}\right)$ substitution rates provides a 
means for detecting adaptive sequence evolution. $\mathrm{A} \mathrm{K}_{\mathrm{a}} / \mathrm{K}_{\mathrm{s}}$ value greater than one in pairwise comparisons of homologous nucleotide sequences provides stringent evidence for diversifying selection (Yang and Bielawski 2000). The region of the $P$. cinnamomi pg genes from the codon encoding the first conserved cysteine (Fig. 2) to the $3^{\prime}$ end of the coding sequence was used in an analysis of $\mathrm{K}_{\mathrm{a}} / \mathrm{K}_{\mathrm{s}}$, while the variable $5^{\prime}$ coding regions were excluded. In the instances when two or more $P$. cinnamomi $p g$ genes were $99 \%$ identical, only one sequence was included in the analysis. Pairwise comparisons of Pcpg1, Pcpg2, Pcpg4 to Pcpg10, Pcpg12, and Pcpg16 to Pcpg19 using the YN00 program did not provide evidence for diversifying selection, because the $\mathrm{K}_{\mathrm{a}} / \mathrm{K}_{\mathrm{s}}$ values were not greater than one in any of the compari- sons. However, diversifying selection in proteins usually affects only a few sites at a few time points (Yang et al. 2000). Selection at most sites is presumably neutral or conservative, and hence, the overall $\mathrm{K}_{\mathrm{a}} / \mathrm{K}_{\mathrm{s}}$ is less than one or is not significantly greater than one, even though some amino acid residues subject to diversifying selection might be present.

In order to detect more subtle diversifying selection, the same set of $P$. cinnamomi $\mathrm{pg}$ genes was analyzed using maximum likelihood models of codon substitution that allow for heterogenous selection pressure along the protein. Of the models available in the CODONML program (Yang et al. 2000), M1, M2, M7, and M8 were implemented. M1 assumes two classes of sites, one with $\mathrm{K}_{\mathrm{a}} / \mathrm{K}_{\mathrm{s}}=0$ (conserved sites), and one

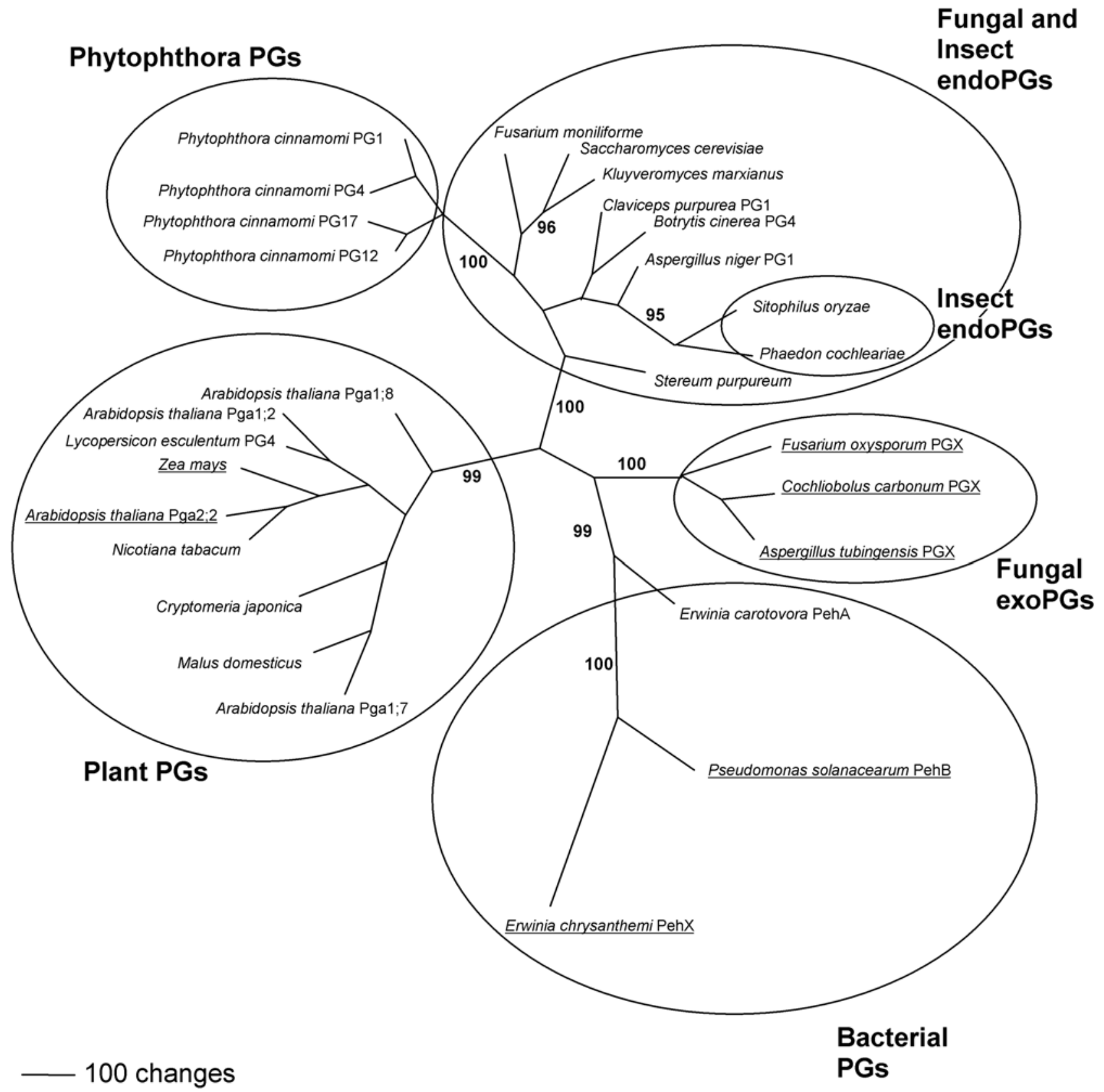

Fig. 5. Phylogenetic tree of bacterial, plant, fungal, animal, and Phytophthora cinnamomi polygalacturonases (PGs). ExoPGs are underlined. Except for the $P$. cinnamomi PGs, the remaining sequences have been demonstrated or designated to be endoPGs or endo/exoPGs. Bootstrap support values are indicated for clades with bootstrap support of 50 or higher. Accession numbers (SWISS-PROT or TrEMBL): A. thaliana Pga1;2 O22818, A. thaliana Pga1;7, O22935; A. thaliana Pga1;8. O48576; A. thaliana Pga2,2, O65401; A. niger PG1, P26213; A. tubingensis PGX, Q00293; B. cinerea PG4, Q9Y7W0; C. carbonum PGX, Q00359; C. purpurea PG1, P78607; C. japonica, P43212; E. carotovora PehA, P26509; E. chrysanthemi PehX, P15922; F. moniliforme, Q07181; F. oxysporum PGX, O74255; K. marxianus, O13478; L. esculentum PG4, Q96488; M. domestica, P48978; N. tabacum, Q05967; P. cochleariae, O97400; P. solanacearum, Q53241; S. cerevisiae, P47180; S. oryzae, AF207068; S. purpureum, P79074; and Z. mays, P26216. 
with $\mathrm{K}_{\mathrm{a}} / \mathrm{K}_{\mathrm{s}}=1$ (neutral sites). M2 allows for diversifying selection by adding a class with $\mathrm{K}_{\mathrm{a}} / \mathrm{K}_{\mathrm{s}}$ estimated from the data. M7 implements a discrete approximation to a beta distribution with ten classes in the interval $0 \leq \mathrm{K}_{\mathrm{a}} / \mathrm{K}_{\mathrm{s}} \leq 1$, and $\mathrm{M} 8$ adds an additional class to allow for sites with $\mathrm{K}_{\mathrm{a}} / \mathrm{K}_{\mathrm{s}}>1$. M1 and $\mathrm{M} 7$ constitute null hypotheses compared with the more general M2 and M8, respectively. When a more general model indicates the presence of a class of sites with $\mathrm{K}_{\mathrm{a}} / \mathrm{K}_{\mathrm{s}}>1$, comparison with its null hypothesis using a likelihood-ratio test constitutes a test for diversifying selection (Yang et al. 2000). M1 was rejected in favor of M2, which allows for positive selection (Table 2). M2 suggested the presence of a small proportion (1.6\%) of amino acid residues subject to diversifying selection (Table 2). An empirical Bayes approach (Nielsen and Yang 1998) identified two residues with a probability $<0.05$ of not having been subject to diversifying selection and two sites with a probability $<0.10$ (Table 3). Similarly, M7 was rejected in favor of M8 (Table 2), which also suggests that some sites have been under diversifying selection pressure. The empirical Bayesian approach identified the same residues subject to diversifying selection that had been identified implementing M2 (Table 3).

Two of the genes included in this analysis, Pcpg5 and Pcpg18, appear to have only recently become pseudogenes and so were assumed to represent the sequence of their functional ancestors accurately. To check this assumption, the analysis was repeated excluding Pcpg5 and Pcpg18, but the result was essentially the same.

It is not clear to what extent maximum-likelihood estimation under these models is affected by reticulate evolution (Yang and Bielawski, 2000). The analysis was, therefore, repeated using several tree topologies, but the result was essentially the same.

The sequences of the $P$. cinnamomi PGs suggest that they are structurally similar to $A$. niger PGII, whose crystal struc-
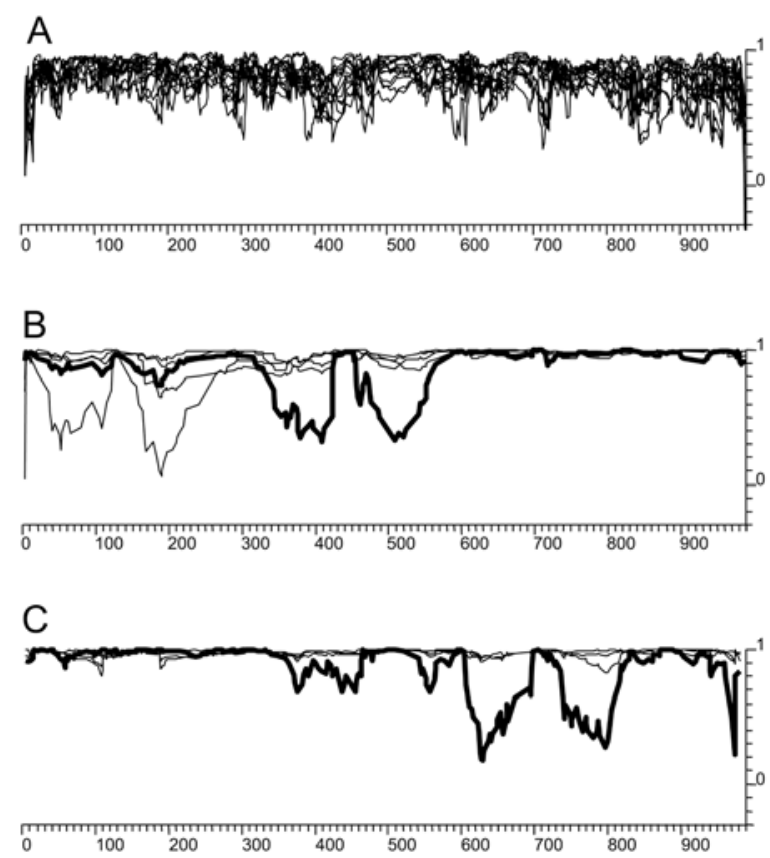

Fig. 6. Phylogenetic profiles of the Phytophthora cinnamomi polygalacturonase $(P c p g)$ genes. The analyzed alignments were $\mathbf{A}$, Pcpg1, Pcpg2, Pcpg4 to Pcpg6, Pcpg8 to Pcpg10, Pcpg12, and Pcpg16 to Pcpg19; B, Pcpg6 (bold), Pcpg4, Pcpg5, Pcpg9, and Pcpg10; and C, Pcpg2 (bold), Pcpg4, Pcpg5, Pcpg12, and Pcpg14. Positions in the alignment are indicated on the $\mathrm{x}$-axis; phylogenetic correlation values on the $y$-axis. Low correlation values near the ends of the alignments were caused by the small size of the upstream or downstream windows at these positions and are not significant. ture has been determined (Protein Data Bank ID 1CZF) (van Santen et al. 1999). The sites identified as undergoing diversifying selection in $P$. cinnamomi corresponded to residues 73 , 86, 91, and 360 of $A$. niger PGII. A model of PcPG4 was constructed using the structures of $A$. niger PGII (van Santen et al. 1999) and Erwinia carotovora PehA (Pickersgill et al. 1998) as templates (Fig. 9A and B). The identified residues were predicted to be located in two separate regions of the protein. Three residues were located in two adjacent turns of the $\beta$-helix, one of them $\left(\mathrm{L}^{95}\right)$ close to the N-terminal end of the active site cleft, one $\left(\mathrm{E}^{90}\right)$ in an extended loop flanking the active site cleft, and one $\left(E^{77}\right)$ on the opposite side of the $\beta$-helix to the active site cleft. According to the model, these three residues are all solvent exposed. The last eight residues of PcPG4, including the one remaining residue subject to diversifying selection $\left(\mathrm{T}^{360}\right)$ could not be modeled, but this residue is presumably shielding the $\mathrm{C}$-terminal end of the core of the $\beta$-helix, as is the corresponding residue $\left(S^{360}\right)$ in $A$. niger PGII (van Santen et al. 1999). PcPG4 $\mathrm{T}^{360}$ is also probably solvent exposed, as is $A$. $n i$ ger PGII $\mathrm{S}^{360}$. The high proportion of charged or polar residues occurring at positions 77, 90, and 360 (Table 4) is also consistent with these residues being solvent exposed. In contrast, about half of the P. cinnamomi PGs had a strongly hydrophobic residue (leucine) at position 95, and the remainder had polar or charged residues (Table 4).

\section{DISCUSSION}

\section{Biological significance}

of the $P$. cinnamomi $\mathrm{pg}$ multigene family.

Although oomycete pathogens, including species of Phytophthora, have been shown to produce pectinases (Cole 1970; Jarvis et al. 1981; Sanchez et al. 1994; Yoshikawa et al. 1977), little is known about these enzymes at the molecular and biochemical level. In this study, we have shown that $P$. cinnamomi contains a large $\mathrm{pg}$ multigene family comprising more than $19 \mathrm{pg}$ genes. Other plant pathogens contain multiple $p g$ genes and many PG isoforms, but the size of the gene family in $P$. cinnamomi is remarkable. Amongst the true fungi, A. niger has seven pg genes and at least nine PG isoforms (Bussink et al. 1992; Stratilová et al. 1993); B. cinerea has at least six genes and produces 13 isoforms (van der Cruyssen et al. 2001; Wubben et al. 1999); and Sclerotinia sclerotiorum has at least seven genes and secretes 14 PG isoforms (Fraissinet-Tachet et al. 1995; Martel et al. 1996). The large number of isoforms in S. sclerotiorum and $B$. cinerea could be due to the presence of additional $\mathrm{pg}$ genes or to posttranslational modifications. The latter situation is exemplified by Fusarium moniliforme, which has four PG isoforms encoded by one gene (Caprari et al. 1996).

The biological significance of multiple PGs in plant pathogens is not fully understood, although a number of possibilities have been proposed. The size of $p g$ multigene families has been suggested to vary with the specificity of the interaction, so that pathogens with wide host ranges have large $p g$ gene families and pathogens with narrow host ranges have few $p g$ genes (EsquerréTugayé et al. 2000). In this context, a large $p g$ gene family might have developed to enable the pathogen to successfully colonize hosts that differ in cell wall structure and composition and in response to the diversity of PGIPs and other defenses encountered in different hosts. The generalization holds true for $B$. cinerea and S. sclerotiorum, which have wide host ranges, and for Colletotrichum lindemuthianum, which is restricted to fabaceous hosts and has only two $p g$ genes. However, it does not hold true for Botrytis species with a narrow host range. Botrytis species restricted to one host contain homologues to all members of the $B$. cinerea pg gene family (Wubben et al. 1999). Nor does it hold true in Phytophthora species. Consistent with the generalization, 
$P$. cinnamomi has a large $p g$ gene family and a very wide host range (Erwin and Ribeiro 1996), but gel blots of $P$. infestans genomic DNA probed with a $P$. cinnamomi $g$ gene fragment show a similarly large number of hybridizing bands (data not shown), suggesting that $P$. infestans has a similar number of $p g$ genes to that in $P$. cinnamomi, even though $P$. infestans is restricted to solanaceous plants, mainly potato and tomato. The apparently large $p g$ gene family of $P$. infestans could be inherited from an ancestor with a wide host range, and as in P. cinnamomi, not all the PG-like sequences may encode functional genes, but it is also possible that factors other than host range could have provided selective pressures leading to the evolution of large $p g$ gene families.

The diversity of PG isoforms may reflect the complexity of the pectin molecules in plant cell walls, and the need for enzymes capable of cleaving the homogalacturonan backbone in a variety of structural contexts. PGs must be able to degrade plant cell walls of different composition and $\mathrm{pH}$ in different tissues and, during parasitic growth, may need to degrade homogalacturonan to completion without allowing intermediate degradation products to accumulate, since oligogalacturonides with a degree of polymerization of 8 to 15 have been shown to elicit plant defenses (Hahn et al. 1989). For these reasons, it seems likely that an array of PGs with a wide range of action patterns, specificities, and abilities to function in different environments would be advantageous to the microorganism.

The presence of temporal and spatial regulation of $p g$ expression in many fungi supports the contention that enzyme specialization is an important feature of fungal pectinolytic systems. It has been proposed, for example, that constitutively secreted PGs in S. sclerotiorum and B. cinerea release monomers that activate the expression of other $p g$ genes, because

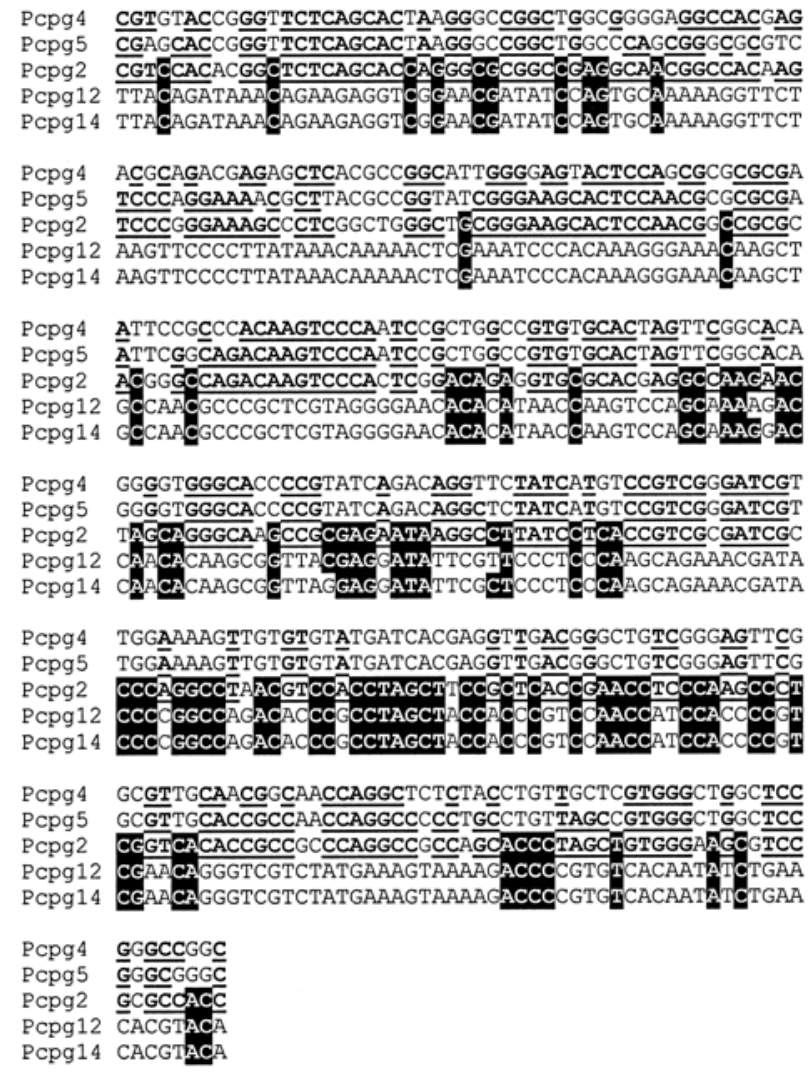

Fig. 7. Analysis of informative sites in $P c p g 2$. Alignment of sequences of Pcpg2, Pcpg4, Pcpg5, Pcpg12, and Pcpg14. Highlighted nucleotides indicate where $P c p g 2$ shares informative sites with genes representative of one or other of the putative ancestral lineages. several other members of the gene family in these pathogens are induced by galacturonic acid (Fraissinet-Tachet and Fevre 1996; Wubben et al. 2000). S. sclerotiorum PG isoforms are sequentially secreted in cultures grown on polygalacturonate medium, suggesting that PG isoforms specific for progressively shorter oligogalacturonides are expressed as degradation of the substrate proceeds (Martel et al. 1998). It is possible that the products released at each stage of the degradation of the pectin polymer, starting with the oligomers produced by early secreted endoPGs, effect the successive induction and repression of $p g$ genes encoding PGs with different biochemical properties, until degradation is complete (Martel et al. 1998). Based on the expression patterns, different $B$. cinerea $p g$ genes are suggested to function in lesion expansion, nutrient provision, and infection in acidic environments (ten Have et al. 2001). These results support the hypothesis that constitutively produced enzymes release degradation products capable of inducing a complex pectinolytic machinery.

\section{Diversity of $P$. cinnamomi PGs.}

PG isoforms participating in an orchestrated attack on plant tissue would be expected to have become adapted to function in different environments and to display different substrate specificities and modes of action. Consistent with this idea, the extensively characterized $A$. niger PGs display considerable differences in biochemical attributes (Benen et al. 1999; Pařenicová et al. 1998, 2000b). Little biochemical characterization of other PGs has been performed, but some conclusions about the diversity of properties and roles of PG isoforms can be drawn from analysis of the primary sequences.

The primary sequences indicate that the $P$. cinnamomi PGs are divided into subgroups with respect to potential glycosylation sites and N- and C-terminal structures (Table 1). Differential glycosylation of PGs is also present in B. cinerea (Wubben et al. 1999), but the division of the $P$. cinnamomi PGs into lightly or potentially heavily $N$-glycosylated isoforms is striking. Potential $N$-glycosylation sites are present on all faces of the potentially heavily glycosylated $P$. cinnamomi PGs but are absent from the active site (Fig. 9C and D). Possible functions of $\mathrm{N}$-glycosylation include conferring stability (Wyss and Wagner 1996) or protease resistance (Rudd et al. 2001) to enzymes secreted into hostile environments. Deglycosylation under nondenaturing conditions of $A$. niger PGs led to complete inactivation, indicating that glycosylation may also be crucial for enzymatic activity (Stratilová et al. 1998). Interestingly, PiPG1 (Torto et al. 2002), which is similar to PcPG12 to

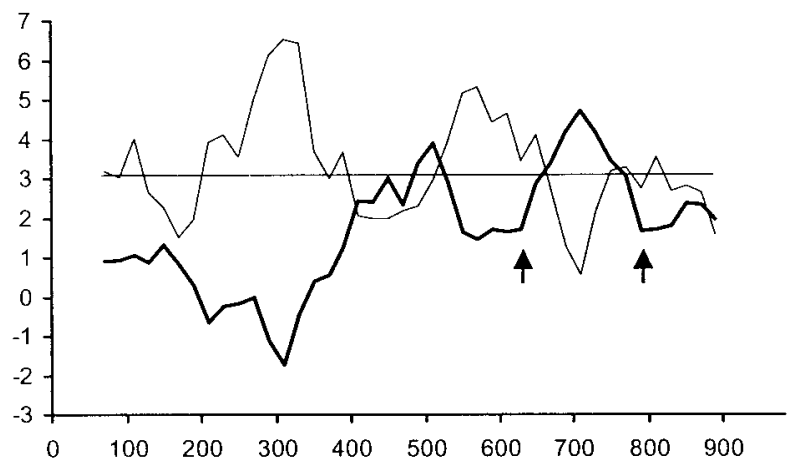

Fig. 8. Reticulate evolution affecting Pcpg2. Changes in Z-scores for patterns for a set of sequences including $P$ cpg2 (putative recombinant), Pcpg5 and Pcpg12 (representing parental lineages), and a randomized outlier are indicated. Positions in the alignment are indicated on the $\mathrm{x}$ axis; $Z$-scores on the $y$-axis. Bold line indicates $Z$-scores for the pattern $(P$ cpg $2=P$ cpg $12 \neq P$ cpg $5 \neq$ outlier $)$, thin line indicates $Z$-scores for the pattern $($ Pcpg $2=P$ cpg $5 \neq$ Pcpg $12 \neq$ outlier $)$. 
PcPG18, is also potentially heavily glycosylated, but most of the putative glycosylation sites are not conserved between $P$. cinnamomi and $P$. infestans.

Another structural feature that might reflect functional diversification in the $P$. cinnamomi PGs is the division into three classes with either no N-terminal extension or with one of two types of extension (Table 1). N-terminal extensions of PGs are diverse compared to the remainder of the protein. Although the $A$. niger PGD (Pařenicová et al. 2000b) and $B$. cinerea PG3 (Wubben et al. 1999) proteins are closely related phylogenetically (Wubben et al. 1999), the N-terminal extensions are dissimilar. Similarly, the two types of extensions in P. cinnamomi PGs are unrelated. A. niger PGD is an endo/exoPG with extreme processive behavior and is thought to be an oligogalacturonase that completely degrades oligomers released by endoPGs, rather than a PG that is involved in the initial attack on the cell wall (Pařenicová et al. 2000b). The mode of action and substrate specificity of $\mathrm{A}$. niger PGD has been suggested to be defined by its extension (Pařenicová et al. 2000b). It has also been suggested that the unique $\mathrm{C}$-terminal extension of $A$. niger rhamnogalacturonase $B$ defines its substrate specificity and distinguishes it from other known rhamnogalacturonases (Suykerbuyk et al. 1997). The C-terminal extension of $A$. niger rhamnogalacturonase $\mathrm{B}$ and the $\mathrm{N}$-terminal extensions of $P$. cinnamomi $\mathrm{PGs}$ all contain glutamine-containing repeat sequences, D(P/Q)TQQQ and NPGQN in $P$. cinnamomi and GEQ in $A$. niger rhamnogalacturonase B (Suykerbuyk et al. 1997), perhaps suggesting a role for glutamine residues in interaction with a particular feature of the pectin molecule.

The complete $P$. cinnamomi PGs had two conserved cysteines predicted to form a disulphide-bonded N-terminal structure capping the $\beta$-helical core as in A. niger PGII (van Santen et al. 1999). All reported eukaryotic PGs have at least one disulphide bridge in the C-terminal region, and PiPG, which appears truncated in the $\mathrm{C}$-terminal region compared to fungal and $P$. cinnamomi $\mathrm{PGs}$, seems to have regained two $\mathrm{C}$-terminal cysteines through a frameshift and a point mutation, indicating that C-terminal disulphide bonding is probably important for PG stability and function. However, PcPG7 to PcPG10 and PcPG19 lack C-terminal cysteine residues (Table 1), but most of these are active when expressed in yeast, suggesting that they may have an alternative $\mathrm{C}$-terminal capping structure.

All eight highly conserved amino acids in the catalytic site of the PG enzymes were conserved in all the PcPGs except for PcPG15, which had $\mathrm{D}^{291} \mathrm{~A}^{292}$ instead of $\mathrm{D}^{291} \mathrm{D}^{292}$. The missing aspartic acid residue in PcPG15 is catalytically active. A conservative site-directed mutation of this residue in A. niger PGII (D to E) reduced the specific activity of the enzyme to approximately $0.5 \%$ of wild-type activity, and mutating the $\mathrm{D}$ residue to $\mathrm{N}$ reduced the specific activity to approximately $0.01 \%$ (Armand et al. 2000). It is, therefore, probable that Pcpg15 does not encode a functional PG (Table 1).
The predicted pIs of the $P$. cinnamomi PGs vary widely. The pI may influence enzyme specificity for substrates with different charge (Bradford 1976). A basic pI may, for example, confer affinity for negatively charged polygalacturonate. Basic pI may also decrease protein mobility within the cell wall, leading to highly localized wall degradation, as observed upon secretion of the extremely basic polygalacturonate lyase by the biotroph Uromyces vicae-fabae (Mendgen et al. 1996).

\section{Relationship \\ of the $P$. cinnamomi PGs with PGs from other taxa.}

It is currently not possible to resolve the eukaryotic phylogeny because of the rapid diversification that gave rise to most, or possibly all, eukaryotic phyla (Philippe et al. 2000). Analysis of small subunit rRNA, $\beta$-tubulin genes, and a large set of $P$. infestans esterases has suggested that heterokonts, including Phytophthora, are either equidistant to fungi and green algae/plants (Förster et al. 1990) or more closely related to green algae/plants than to fungi (Kamoun et al. 1999; Weerakoon et al. 1998). The present study extends the recent finding by Torto and associates (2002) that PiPG is more similar to fungal and insect endoPGs (Fig. 5) than to any other PG. Convergent evolution of the PGs of fungi and oomycetes or conservation of features of the ancestral protein are possible explanations for the phylogenetic affiliation of the $P$. cinnamomi PGs and fungal endoPGs. Plant pectic substrates and defenses against pathogen attack may provide similar selective pressures for microorganisms from different phyla, while plants are likely to have had different requirements in terms of the mode of action and substrate specificity of their own PGs. Another possible explanation is horizontal gene transfer between the fungal and heterokont lineages. Analysis of insertions and deletions in an alignment of all reported PG sequences showed that $P$. cinnamomi PGs and fungal endoPGs shared only one deletion not present in other PGs. However, other insertions and deletions and introns were not at conserved positions in $P$. cinnamomi PGs and fungal endoPGs. Furthermore, codon usage and GC content in the $P$. cinnamomi $p g$ genes did not distinguish these genes from other reported $P$. cinnamomi genes. If oomycetes have acquired $p g$ genes, the absence of evidence for horizontal gene transfer in the $P$. cinnamomi pg sequences might be due to adaptation of the sequences to the codon preferences and processing constraints of the P. cinnamomi genome.

\section{Evolution of the $P$. cinnamomi pg multigene family.}

The existence of pairs of almost identical genes in the $P$. cinnamomi pg gene family is likely to be due to recent duplication events. The presence of recently duplicated genes and genes that have acquired mutations leading to loss of function (Table 1) indicate that the gene family is undergoing a process of birth-and-death evolution (Nei and Hughes 1992). Pg genes that appear to be recently duplicated are also present in $S$. sclerotiorum (Fraissinet-Tachet et al. 1995) and in Claviceps

Table 2. Probabilities of various distributions of Phytophthora cinnamomi polygalacturonase sites with respect to $\mathrm{K}_{\mathrm{a}} / \mathrm{K}_{\mathrm{s}}$ values

\begin{tabular}{|c|c|c|c|c|c|c|}
\hline Model $^{\mathbf{a}}$ & Proportion of sites in classes with $K_{a} / K_{s}>1$ & $\mathbf{K}_{\mathbf{a}} / \mathbf{K}_{\mathrm{s}}$ & $\ln L^{b}$ & $\chi^{2 \mathrm{c}}$ & Degrees of freedom & Probability \\
\hline M1 & $\mathrm{NA}^{\mathrm{d}}$ & NA & -8475.422 & NA & NA & NA \\
\hline M2 & 0.016 & 6.17 & -8463.203 & 24.438 & 2 & $<0.01$ \\
\hline M7 & NA & NA & -7896.923 & NA & NA & NA \\
\hline M8 & 0.016 & 1.50 & -7891.308 & 11.230 & 2 & $<0.01$ \\
\hline
\end{tabular}

${ }^{a} \mathrm{M} 1=$ neutral $\left(\mathrm{K}_{\mathrm{a}} / \mathrm{K}_{\mathrm{s}}=0\right.$ or $\mathrm{K}_{\mathrm{a}} / \mathrm{K}_{\mathrm{s}}=1$ ), $\mathrm{M} 2$ = selection (one class with $\mathrm{K}_{\mathrm{a}} / \mathrm{K}_{\mathrm{s}} \neq 1$ added to $\mathrm{M} 1$ ), $\mathrm{M} 7$ = discrete approximation to beta distribution with 10 classes in the interval $0 \leq \mathrm{K}_{\mathrm{a}} / \mathrm{K}_{\mathrm{s}} \leq 1, \mathrm{M} 8=\mathrm{M} 7$ with an extra class added to allow for a class with $\mathrm{K}_{\mathrm{a}} / \mathrm{K}_{\mathrm{s}}>1$. Program used for analysis: CODONML 3.0a (Yang et al., 2000).

${ }^{\mathrm{b}}$ Log likelihood.

${ }^{\mathrm{c}}$ Likelihood ratio test: $\chi^{2}=2\left(\ln \mathrm{L}_{\text {alternative hypothesis }}-\ln \mathrm{L}_{\text {null hypothesis }}\right)$.

${ }^{\mathrm{d}} \mathrm{NA}=$ not applicable. 
purpurea (Tenberge et al. 1996), but the $p g$ gene families of $A$. niger and $B$. cinerea seem to be evolutionarily stable, containing only functional $p g$ genes and no pseudogenes (Benen et al. 1999; Pařenicová et al. 1998, 2000a, 2000b; Wubben et al. 1999).

The organization of the $P$. cinnamomi $p g$ genes suggests a possible mechanism for the initiation of gene family growth. The members of each pair of nearly identical genes are in inverted orientation with respect to one another. However, apart from three recent duplications, there is a tendency for repeated genes to be in direct orientation. If duplication involves production of inverted repeats, this might be an unstable arrangement, and the gene might need to undergo a second duplication, before an inverted copy is lost in order to achieve a net gain of one gene in direct orientation. Comparison of a segment of tomato chromosome 2 with syntenous segments of the A. thaliana genome showed several examples of conservation of gene order but not of gene orientation ( $\mathrm{Ku}$ et al. 2000). A model was proposed in which gene duplication events give rise to inverted repeats, followed by loss of the original gene, leading to change in gene orientation ( $\mathrm{Ku}$ et al. 2000). An inverted repeat duplication mechanism is consistent with the organization of the two almost identical $P$. infestans ipiO genes (Pieterse et al. 1994) (inverted orientation) and the more divergent Phytophthora elicitin genes (Duclos et al. 1998; Mao and Tyler 1996; Panabières et al. 1995) (direct orientation). However, the three $P$. infestans ipiB genes (96\% identical) whose intergenic regions are still $98 \%$ identical, indicating recent duplication, are arranged in direct orientation.

After the initial generation of a direct tandem repeat through the mechanism suggested above, there is the potential for mispairing by strand slippage at meiosis and recombination to increase or decrease the gene number and to allow genetic exchange between nonorthologous genes, as has been postulated for many R gene families in plants (Ellis et al. 2000) and for $P$. cinnamomi $p g$ genes in this study. Reticulate evolution may be an important mechanism in the evolution of the P. cinnamomi $p g$ gene family, because it has the potential to accelerate the development of pathogen fitness, including the ability to avoid inhibition by PGIPs. The evolutionary importance of recombination has been extensively investigated in the tomato $\mathrm{Hcr} 9$ genes (Parniske and Jones 1999), a family of resistance genes involved in an evolutionary arms race with fungal avirulence genes. A model has been presented in which sequence exchange is prevented from leading to excessive homogenization by physical and genetic separation of gene clusters, which suppresses mispairing and recombination. A rare ectopic recombination event was shown to have introduced a gene from one cluster of $\mathrm{Hcr} 9$ genes to a distant, diverged cluster, and subsequent recombination with other genes in the recipient cluster has generated novel gene structures (Parniske and Jones 1999). This model may be applicable to the $P$. cinnamomi $p g$ genes. Greater structural similarities and more frequent intercluster recombination events suggest that cluster I, cluster II, and Pcpg19 may be in closer physical proximity to one another than to Pcpg12 to Pcpg18. No whole gene seems to have been transferred between the lightly and heavily glycosylated subgroups, but the possible ectopic recombination event involving Pcpg2 depicted in Figures 6C and 7 indicates that genetic exchange may occur between divergent $P$. cinnamomi pg gene subgroups to create novel combinations of structural features.

The $P$. cinnamomi pg sequences generated by gene duplications and modified by mutation and recombination may also have undergone adaptive evolution. The similarity between $P$. cinnamomi and fungal PGs (Fig. 5) and the fact that the residues possibly subject to diversifying selection are solvent exposed (Fig. 9) suggests that one source of the selective pressure behind the adaptive evolution of the $P$. cinnamomi PGs could be interaction with PGIPs. A single amino acid substitution can confer a new PG target specificity upon closely related PGIPs (Leckie et al. 1999), indicating that small structural changes may confer great advantages in the evolutionary arms race. The residues subject to diversifying selection identified in fungal PGs (Stotz et al. 2000) and in this study are widely separated over the PG protein but are not situated in the catalytic site. This need not mean that PGIPs do not drive diversifying selection in PGs. It is not known which regions of PGs interact with PGIPs (Leckie et al. 1999), and some PGIPs have a noncompetitive mode of inhibition (Yao et al. 1995), consistent with interactions with PG residues outside the catalytic site. Moreover, an inhibitor binding outside the catalytic site might effect competitive inhibition indirectly by preventing substrate access.

None of the fungal residues likely to be subject to diversifying selection (Stotz et al. 2000) correspond to any of the residues identified in the present study. If certain regions of PGs from different taxa are consistently important in interactions with PGIPs, the sets of identified residues might be expected to overlap, but this does not seem to be the case. Similarly, entirely different sets of positively selected residues were identified in the analysis of two different selections of plant PGIPs, indicating that those residues in PGIPs that are both under diversifying selection and free to respond differ between groups of plants (Stotz et al. 2000).

Another possible diversifying selective pressure is proteolytic attack. $P$. cinnamomi PG residue 360 (Table 4) is probably part of the capping structure at the C-terminus of the PG protein. It is conceivable that the host secretes proteases aimed at the degradative enzymes of the pathogen and that the ends of the $\beta$-helix might be targets for attack. Variations in capping structure residues might protect a certain proportion of the PGs from proteolytic attack in any given situation.

This study has shown that $p g$ genes form a major gene family in $P$. cinnamomi and indicates that the genes encode structurally diverse isoforms. Just as plants have responded to selection pressure imposed by plant pathogens by evolving large multigene families, it would seem that $P$. cinnamomi has responded to selective pressure imposed by plants by likewise evolving a large $p g$ multigene family by similar mechanisms. Birth-and-death evolution, reticulate evolution, and adaptive evolution may have contributed to the development of the large $P$. cinnamomi $p g$ gene family. PGs are important in saprophytic and parasitic growth and, therefore, have been the focus of much study in fungi. The $P$. cinnamomi $\mathrm{pg}$ gene family exhibits intriguing differences compared with true fungi and warrants further investigation. Future work will examine the features and functional abilities of $P$. cinnamomi $\mathrm{PG}$ proteins, the regulation of $P$. cinnamomi $p g$ gene expression during plant infection, and the possible inhibition of $P$. cinnamomi PGs by plant PGIPs.

Table 3. Probabilities that amino acid sites in the Phytophthora cinnamomi polygalacturonases do not belong to the class of sites under diversifying selection pressure

\begin{tabular}{lcc}
\hline & \multicolumn{2}{c}{ Probability $(\boldsymbol{P})$} \\
\cline { 2 - 3 } Site $^{\mathbf{a}}$ & $\mathbf{M 2}^{\mathbf{b}}$ & M8 \\
\hline $77(73)$ & 0.001 & 0.017 \\
$90(86)$ & 0.017 & 0.065 \\
$95(91)$ & 0.076 & 0.243 \\
$360(360)$ & 0.051 & 0.068 \\
\hline
\end{tabular}

a Position in the unprocessed PcPG4 protein is indicated and in brackets position of the corresponding residue in the unprocessed Aspergillus niger PGII is indicated.

${ }^{b}$ M2 allows for diversifying selection by adding a class with $\mathrm{K}_{\mathrm{a}} / \mathrm{K}_{\mathrm{s}}$ estimated from the data. M8 adds an additional class to allow for sites with $\mathrm{K}_{\mathrm{a}} / \mathrm{K}_{\mathrm{s}}>1$. 


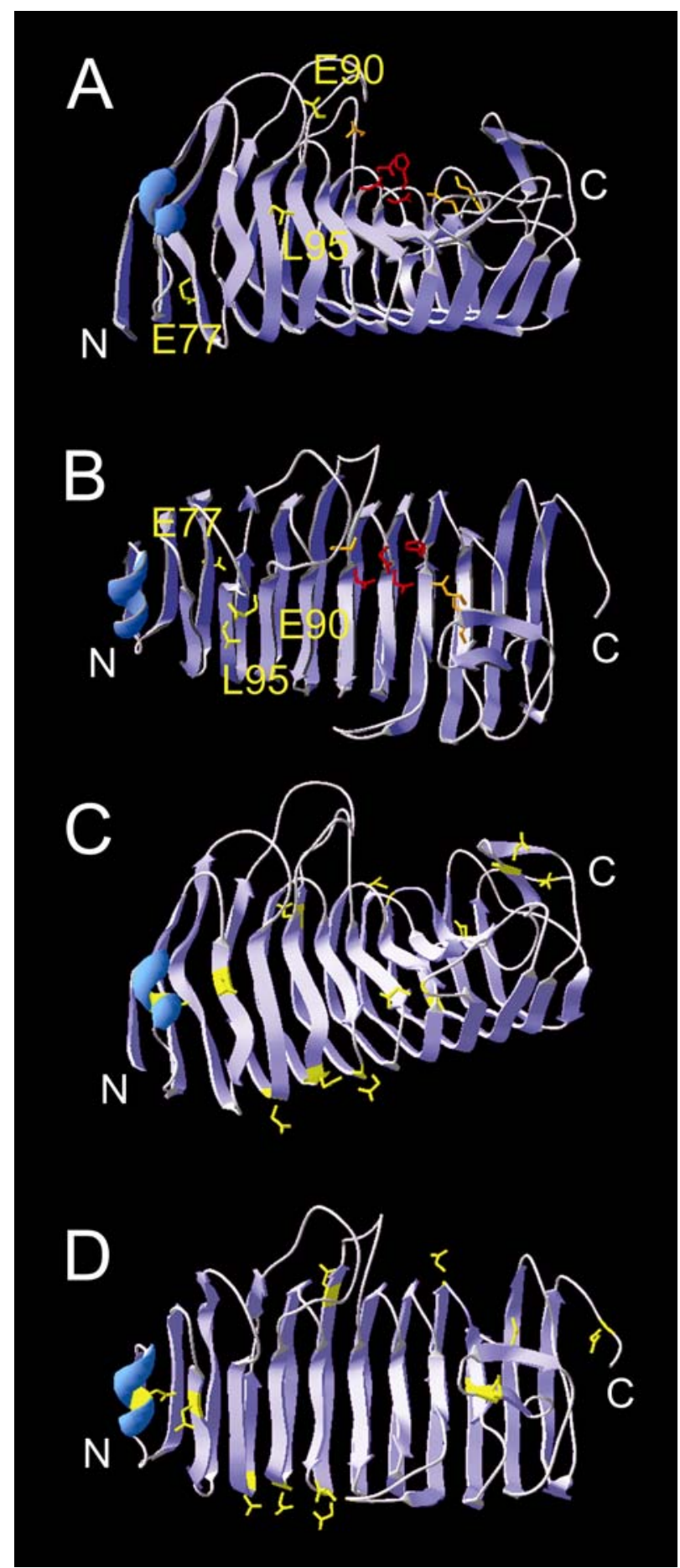

Fig. 9. Amino acid residues in Phytophthora cinnamomi polygalacturonases (PGs) that have been subject to diversifying selection and position of $N$-glycosylation sites. Models of $P$. cinnamomi PGs were made using the crystal structures of A. niger endoPGII and E. carotovora PehB as templates. The PG molecule consists of $\beta$ strands forming a $\beta$ helix. While most of the hinge regions that connect the $\beta$-strands of the $\beta$ helix are only a few residues long, some are elongated and form the active site cleft. A, Model of PcPG4 showing the active site cleft from the Nterminal end. The amino $(\mathrm{N})$ and carboxyl $(\mathrm{C})$ termini of the protein are indicated. B, Top view looking down into the active site cleft of PcPG4. The side chains of the residues identified as subject to diversifying selection are shown in yellow. Three of the residues $\left(\mathrm{E}^{77}, \mathrm{E}^{90}\right.$, and $\left.\mathrm{L}^{95}\right)$ are located on two adjacent turns of the $\beta$-helix and $\mathrm{T}^{360}$ is located at the $\mathrm{C}$-terminus. $\mathrm{T}^{360}$ is not shown since the C-terminus could not be modeled. Catalytically important residues (Armand et al. 2000) are shown in red, and other residues that are conserved in PGs are shown in orange. $\mathbf{C}$, and $\mathbf{D}$, Similar view to A and B showing a model of PcPG16 with asparagine residues in the potential $\mathrm{N}$-glycosylation sites of PcPG16 indicated in yellow.

\section{MATERIALS AND METHODS}

Strain of $P$. cinnamomi used and culture conditions.

A strain of $P$. cinnamomi (H1000, DAR 52646, ATCC 200982) isolated from a soil sample taken in the Brisbane Ranges, Victoria, Australia, was maintained on V8 agar (Hardham et al. 1991). Sterile $250 \mathrm{ml}$ Ehrlenmeyer flasks containing $80 \mathrm{ml}$ of V8 broth were inoculated with 10 small cubes of agar excised from the periphery of a $P$. cinnamomi colony after 3 days of growth. The cultures were incubated at $25^{\circ} \mathrm{C}$ until harvest of hyphae or collection of the growth medium.

\section{Isolation of protein.}

Four $80 \mathrm{ml} \mathrm{P}$. cinnamomi liquid cultures were filtered through two layers of miracloth after 4 days of growth. The culture filtrates were pooled, and proteins were precipitated by gradual addition of $\left(\mathrm{NH}_{4}\right)_{2} \mathrm{SO}_{4}$ to a total concentration of 0.57 $\mathrm{g}$ per $\mathrm{ml}$. The sample was left to precipitate overnight at $4^{\circ} \mathrm{C}$ and then centrifuged at $12,000 \mathrm{~g}$ for $10 \mathrm{~min}$. The pellet was dissolved in $1 \mathrm{ml}$ of $50 \mathrm{mM}$ sodium acetate buffer $(\mathrm{pH} 4.2)$ containing $0.15 \mathrm{M} \mathrm{NaCl}$. The sample was transferred to dialysis tubing and dialyzed in $1 \mathrm{l}$ of acetate buffer for $24 \mathrm{~h}$, with a change of buffer every $8 \mathrm{~h}$. Protein concentrations were determined according to Bradford (1976) using Bio-Rad (Hercules, CA, U.S.A.) protein assay reagents and bovine serum albumin as the protein standard.

\section{PG activity assays.}

PG activity in P. cinnamomi culture filtrates was detected using the 2-cyanoacetamide assay described by Gross (1982) and the ruthenium red gel staining assay described by Collmer and associates (1988). Three replicates of each PG activity assay were performed.

\section{Isolation of $P$. cinnamomi pg genes.}

Using degenerate primers, a polygalacturonase $(p g)$ gene fragment was amplified from $P$. cinnamomi genomic DNA isolated as described by Dudler (1990). The sequences of the oligonucleotide primers were: 5' GTIIAIAA(C/T)CA (A/G)GA(C/T)GA(C/T)TG 3', 5' CCAI(C/G)T(C/T)TT(A/G)ATIC (G/T) IAIICC(A/G)TT $3^{\prime}$. The PCR program was: $94^{\circ} \mathrm{C}$ for $3 \mathrm{~min}$, then 35 cycles of $96^{\circ} \mathrm{C}$ for $45 \mathrm{~s}, 50^{\circ} \mathrm{C}$ for $1 \mathrm{~min}$, and $72^{\circ} \mathrm{C}$ for $1 \mathrm{~min}$, and then one cycle of $72^{\circ} \mathrm{C}$ for $1 \mathrm{~min}$.

A P. cinnamomi genomic DNA library in $\lambda$ EMBL3 (Weerakoon et al. 1998) was screened with the $p g$ gene fragment as a probe following standard protocols (Sambrook et al. 1989). $\lambda$ EMBL3 phage were purified from plate lysates, and phage DNA was prepared using a small scale phage DNA isolation method (Sambrook et al. 1989). SalI fragments of insert DNA were ligated to SalIdigested pBluescript $\mathrm{KS}+$ and used to transform Escherichia coli strain $\mathrm{DH} 5 \alpha$. In some cases, subclones were also made using PstI, HindIII, and XhoI when SalI subclones were inconveniently small or in order to obtain overlapping subclones. Standard methods were used for subcloning, preparation of plasmid DNA, and DNA gel blot analysis (Sambrook et al. 1989).

\section{Sequencing and sequence analysis.}

Cycle sequencing was performed using BIG DYE chemistry (Perkin Elmer Applied Biosystems, Foster City, CA, U.S.A.). Large plasmid clones were sequenced using primer walking or nested deletions generated by an Erase-a-Base kit (Promega, Madison, WI, U.S.A.). Subclones were sequenced in both strands and ordered into contigs using restriction mapping of phage clones and comparison of overlapping plasmid subclones. Sequence data were analyzed using appropriate programs in the Wisconsin GCG Package vs. 8.1-UNIX (Genetics Computer Group, Madison, WI, U.S.A.). Protein database 
searches were performed using the BLASTX program (Altschul et al. 1997).

\section{Evolutionary analysis and protein structure modeling.}

For phylogenetic analysis, deduced PG amino acid sequences were aligned using Pileup in the Wisconsin GCG Package v. 8.1-UNIX (Genetics Computer Group) and the alignments were adjusted manually. Highly variable regions in the amino and carboxyl termini were excluded. Phylogenetic analysis by weighted parsimony was performed using PAUP* v. 4.0b4a (Swofford 1998), and the PROTPARS matrix (Felsenstein 1993) was used to weight changes among amino acids. Bootstrap replicates $(1,000)$ were performed.

Reticulate evolution was detected using Sawyer's runs test (implemented in GENECONV 1.81) (Sawyer 1999) to analyze shared polymorphisms in a 990-basepair-long DNA alignment that excluded the variable $5^{\prime}$ regions of the genes upstream of the codon encoding the first conserved cysteine. Sawyer's runs test searches an alignment and finds identical or almost identical fragments in pairs of sequences. In our analysis, mismatches were allowed (the GENECONV parameter gscale was set to 1). The significance of the hypothesis that a shared fragment arose through reticulate evolution is estimated by comparison with data sets obtained through random permutation of the columns of the real data set. The "pairwise" probability $(P)$ value for a fragment is the proportion of the permutated alignments having a fragment as long or longer than the observed fragment in the same sequence pair. In a large alignment some fragments with low pairwise $P$ values would be expected by chance. Therefore a "global" permutation $P$ value for a certain fragment found in two sequences is calculated as the proportion of permutated alignments having a fragment as long or longer than the observed fragment in any of its sequence pairs. Global $P$ values protect against the statistical artifact that some comparisons may produce fragments with seemingly significant pairwise $P$ values by chance.

The same alignment was also explored for further evidence of reticulate evolution by analysis of parsimoniously informative sites (sites where at least two different nucleotides are present in at least two sequences each) using PhylPro (Weiller 1998). For each site in a given sequence of the alignment, PhylPro evaluates how well the pairwise distances between the sequence in question and the other sequences in the alignment correlate upstream and downstream of that site. For each nucleotide position, distance data were calculated by pairwise comparison from an upstream and a downstream window of parsimoniously informative positions. In our analysis, the window limits were set to 15 differences. The correlation between the two sets of distance data is called the phylogenetic correlation. The phylogenetic correlation data for each sequence in the alignment are then shown graphically as phylogenetic profiles. If the phylogenetic correlation for a sequence is very low at a certain site and stands out in the phylogenetic profile graph as a downward spike, this position is a likely site of past recombination in that sequence.
In the maximum chi-squared method (Maynard Smith 1992), implemented in START (Jolley et al. 2001), polymorphic sites $(n)$ are defined as sites polymorphic in the putative recombinant and two parental sequences. The recombinant and the parents are compared, and in each comparison the number of differences $(s)$ is determined. When an arbitrary cut is made at the $k$ th site, the recombinant and each parent differ at $r / k$ sites before the cut and $(s-r) /(n-k)$ sites after the cut. For each site the value $c$ is calculated as the value of $\chi^{2}$ for a $2 \times 2$ matrix with the proportion of differences between each parent and the recombinant in each of the rows of the matrix, and the optimal recombination breakpoint occurs after the site with the highest $c$ value. The significance of a division is tested by generating random sequence pairs of length $n$ differing at $s$ sites and comparing $c_{\max }$ for these sequences with $c_{\max }$ for the real data. The method is based on the assumption that the investigated region contains only one recombination breakpoint, and alignments containing more than one breakpoint are analyzed in steps.

The sister-scanning method, implemented in SiScan 2.0 (Gibbs et al. 2000), passes a sliding window over an alignment comprising a putative recombinant, two parental sequences, and an outlier. The outlier is a real sequence or a randomized sequence generated for each position of the window by randomizing the positions of the nucleotides within the window in one of the real sequences. Including a randomized outlier decreases the risk of false positives that are due to compositional similarity in the genes. At each position of the window, the number of sites that conform to each of the possible patterns of equality and inequality are counted. For each position of the window, four randomized sequences are generated by assigning a new nucleotide at each position chosen at random, without replacement, from the nucleotides that occur at that position in the real sequences, and the number of sites conforming to each possible pattern is counted. This is repeated 100 times to create a population of scores from randomized sequences, and a $Z$-score for each of the patterns is calculated. In our analysis, a window size of 150 sites, a step size of 20 sites, and an outlier generated by randomization from the putative recombinant were used.

To test for diversifying selection, the ratio between the number of nonsynonymous substitutions per nonsynonymous site $\left(\mathrm{K}_{\mathrm{a}}\right)$ and the number of synonymous substitutions per synonymous site $\left(\mathrm{K}_{\mathrm{s}}\right)$ in pairwise comparisons of $P$. cinnamomi pg sequences were estimated using the methods of Yang and Nielsen (2000) and Nei and Gojobori (1986), which are implemented in YN00 in the PAML package vs. 3.0a (Yang et al. 2000). To implement a more sensitive test for diversifying selection and to detect codons undergoing diversifying selection, the CODONML program in the PAML package version 3.0a (Yang et al. 2000) was used.

The SwissModel First Approach Mode and the SwissPdbViewer (Geux and Peitsch 1997; Peitsch 1995, 1996) were used to align $P$. cinnamomi $\mathrm{PG}$ sequences to the known structures of $A$. niger endoPGII and E. carotovora PehA and to view and analyze the models produced.

Table 4. Amino acid substitutions present at each of the sites apparently undergoing diversifying selection in the Phytophthora cinnamomi PGs

\begin{tabular}{|c|c|c|c|c|c|c|c|c|c|c|c|c|c|c|}
\hline \multirow[b]{2}{*}{ Site $^{a}$} & \multicolumn{14}{|c|}{ PcPG } \\
\hline & 1 & 2 & 4 & 5 & 6 & 7 & 8 & 9 & 10 & 12 & 16 & 17 & 18 & 19 \\
\hline 77 (73) & $\mathrm{T}$ & $\mathrm{K}$ & $\mathrm{E}$ & V & V & $\mathrm{E}$ & $\mathrm{E}$ & Q & $\mathrm{T}$ & $\mathrm{S}$ & $\mathrm{S}$ & $\mathrm{K}$ & $\mathrm{T}$ & $Q$ \\
\hline $90(86)$ & $\mathrm{S}$ & A & $\mathrm{E}$ & $\mathrm{S}$ & $\mathrm{S}$ & E & $\mathrm{E}$ & V & A & D & $\mathrm{S}$ & $\mathrm{S}$ & $\mathrm{S}$ & $\mathrm{N}$ \\
\hline $95(91)$ & $\mathrm{S}$ & $\mathrm{L}$ & $\mathrm{L}$ & $\mathrm{L}$ & $\mathrm{L}$ & $\mathrm{R}$ & Q & $\mathrm{L}$ & $\mathrm{L}$ & $\mathrm{K}$ & $\mathrm{N}$ & $\mathrm{L}$ & $\mathrm{L}$ & $\mathrm{T}$ \\
\hline $360(360)$ & $\mathrm{T}$ & $\mathrm{T}$ & $\mathrm{T}$ & $S$ & D & S & $\mathrm{S}$ & $\mathrm{A}$ & D & $\mathrm{K}$ & $\mathrm{P}$ & $\mathrm{L}$ & $\mathrm{P}$ & A \\
\hline
\end{tabular}

${ }^{a}$ Position in the unprocessed PcPG4 protein; position of the corresponding residue in the unprocessed Aspergillus niger PGII as indicated in brackets. 


\section{ACKNOWLEDGMENTS}

We thank J. Trueman for assistance with phylogenetic analysis, G. Weiller, and G. Huttley for assistance with analysis of reticulate evolution, Z. Yang for comments on the detection of diversifying selection, V. Maclean for technical assistance, and T. Magill for assistance with illustrations.

\section{LITERATURE CITED}

Altschul, S. F., Madden, T. L., Schäffer, A. A., Zhang, J., Zhang, Z., Miller, W., and Lipman, D. J. 1997. Gapped BLAST and PSI-BLAST: A new generation of protein database search programs. Nucleic Acids Res. 25:3389-3402.

Annis, S. L., and Goodwin, P. H. 1997. Recent advances in the molecular genetics of plant cell wall-degrading enzymes produced by plant pathogenic fungi. Eur. J. Plant Pathol. 103:1-14.

Armand, S., Wagemaker, M. J. M., Sánchez-Torres, P., Kester, H. C. M., van Santen, Y., Dijkstra, B. W., Visser, J., and Benen, J. A. E. 2000. The active site topology of Aspergillus niger endopolygalacturonase II as studied by site-directed mutagenesis. J. Biol. Chem. 275:691-696.

Benen, J. A. E., Kester, H. C. M., and Visser, J. 1999. Kinetic characterization of Aspergillus niger N400 endopolygalacturonases I, II, and C. Eur. J. Biochem. 259:577-585.

Bjellqvist, B., Hughes, G. J., Pasquali, C., Paquet, N., Ravier, F., Sanchez, J.-C., Frutiger, S., and Hochstrasser, D. 1993. The focusing positions of polypeptides in immobilized $\mathrm{pH}$ gradients can be predicted from their amino acid sequences. Electrophoresis 14:1023-1031.

Bowen, J. K., Templeton, M. D., Sharrock, K. R., Crowhurst, R. N., and Rikkerink. E. H. A. 1995. Gene inactivation in the plant pathogen Glomerella cingulata: three strategies for the disruption of the pectin lyase gene pnlA. Mol. Gen. Genet. 246:196-205.

Bradford, M. M. 1976. A rapid and sensitive method for the quantification of microgram quantities of protein utilizing the principle of protein-binding dye. Anal. Biochem. 72:248-254.

Bussink, H. J. D., Buxton, F. P., Fraaye, B. A., de Graaff, L. H., and Visser, J. 1992. The polygalacturonases of Aspergillus niger are encoded by a family of diverged genes. Eur. J. Biochem. 208:83-90.

Caprari, C., Mattei, B., Basile, M. L., Salvi, G., Crescenzi, V., De Lorenzo, G., and Cervone, F. 1996. Mutagenesis of endopolygalacturonase from Fusarium moniliforme: Histidine residue 234 is critical for enzymatic and macerating activities and not for binding to polygalacturonase-inhibiting protein (PGIP). Mol. Plant-Microbe Interact. 9:617-624.

Carpita, N. C., and Gibeaut, D. M. 1993. Structural models of primary cell walls in flowering plants: Consistency of molecular structure with the physical properties of the walls during growth. Plant J. 3:1-30.

Cervone, F., Hahn, M. G., De Lorenzo, G., Darvill, A., and Albersheim, P. 1989. Host-pathogen interactions XXXIII. A plant protein converts a fungal pathogenesis factor into an elicitor of plant defense responses. Plant Physiol. 90:542-548.

Cervone, F., De Lorenzo, G., Pressey, R., Darvill, A. G., and Albersheim, P. 1990. Can Phaseolus PGIP inhibit pectic enzymes from microbes and plants? Phytochem. 29:447-449.

Cole, A. L. J. 1970. Pectic enzyme activity from Phytophthora infestans. Phytochem. 9:337-340.

Collmer, A., Ried, J. L., and Mount, M. S. 1988. Assay methods for pectic enzymes. Methods Enzymol. 161:329-335.

Cook, B. J., Clay, R. P., Bergmann, C. W., Albersheim, P., and Darvill, A. G. 1999. Fungal polygalacturonases exhibit different substrate degradation patterns and differ in their susceptibilities to polygalacturonaseinhibiting proteins. Mol. Plant-Microbe Interact. 12:703-711.

Cooper, R. M. 1983. The mechanisms and significance of enzymic degradation of host cell walls by parasites. Pages 101-135 in: Biochemical Plant Pathology. J. A. Callow, ed. John Wiley \& Sons, Chichester, U.K.

Darvill, A., Bergmann, C., Cervone, F., De Lorenzo, G., Ham, K.-S., Spiro, M. D., York, W. S., and Albersheim, P. 1994. Oligosaccharins involved in plant growth and host-pathogen interactions. Biochem. Soc. Symp. 60:89-94.

Desiderio, A., Aracri, B., Leckie, F., Mattei, B., Salvi, G., Tigelaar, H., Van Roekel, J. S. C., Baulcombe, D. C., Melchers, L. S., De Lorenzo, G., and Cervone, F. 1997. Polygalacturonase-inhibiting proteins (PGIPs) with different specificities are expressed in Phaseolus vulgaris. Mol. Plant-Microbe Interact. 10:852-860.

Duclos, J., Fauconnier, A., Coelho, A.-C., Bollen, A., Cravador, A., and Godfroid, E. 1998. Identification of an elicitin gene cluster in Phytophthora cinnamomi. DNA Sequence 9:231-237.

Dudler, D. 1990. The single-copy actin gene of Phytophthora megasperma encodes a protein considerably diverged from any other known actin. Plant Mol. Biol. 14:415-422.

Ellis, J., Dodds, P., and Pryor, T. 2000. Structure, function and evolution of plant disease resistance genes. Curr. Opin. Plant Biol. 3:278-284.
Erwin, D. C. and Ribeiro, O. K. 1996. Phytophthora Diseases Worldwide. American Phytopathological Society Press, St. Paul, MN, U.S.A.

Esquerré-Tugayé, M.-T., Boudart, G. and Dumas, B. 2000. Cell wall degrading enzymes, inhibitory proteins, and oligosaccharides participate in the molecular dialogue between plants and pathogens. Plant Physiol. Biochem. 38:157-163.

Felsenstein, J. 1993. PHYLIP (Phylogeny Inference Package) version 3.5c. Dept. of Genetics, University of Washington, Seattle, U.S.A.

Förster, H., Coffey, M. D., Elwood, H., and Sogin, M. L. 1990. Sequence analysis of the small subunit ribosomal RNAs of three zoosporic fungi and implications for fungal evolution. Mycologia 82:306-312.

Fraissinet-Tachet, L., Reymond-Cotton, P., and Fevre, M. 1995. Characterization of a multigene family encoding an endopolygalacturonase in Sclerotinia sclerotiorum. Curr. Genet. 29:96-100.

Fraissinet-Tachet, L., and Fevre, M. 1996. Regulation by galacturonic acid of pectinolytic enzyme production by Sclerotinia sclerotiorum. Curr. Microbiol. 33:49-53.

Gao, S., Choi, G. H., Shain, L., and Nuss, D. L. 1996. Cloning and targeted disruption of enpg-1, encoding the major in vitro extracellular endopolygalacturonase of the chestnut blight fungus, Cryphonectria parasitica. Appl. Environ. Microbiol. 62:1984-1990.

García-Maceira, F. I., Di Pietro, A., and Roncero, M. I. G. 2000. Cloning and disruption of pgx4 encoding an in planta expressed exopolygalacturonase from Fusarium oxysporum. Mol. Plant-Microbe Interact. 13:359-365.

Geux, N., and Peitsch, M. C. 1997. SWISS-MODEL and the SwissPdbviewer: An environment for comparative protein modeling. Electrophoresis 18:2714-2723.

Gibbs, M. J., Armstrong, J. S., and Gibbs, A. J. 2000. Sister-Scanning: A Monte Carlo procedure for assessing signals in recombinant sequences. Bioinformatics 16:573-582.

Gross, K. C. 1982. A rapid and sensitive spectrophotometric method for assaying polygalacturonase using 2-cyanoacetamide. HortScience 17:933-934.

Hahn, M. G., Bucheli, P., Cervone, F., Doares, S. H., O’Neill, R. A., Darvill, A., and Albersheim, P. 1989. Roles of cell wall constituents in plant-pathogen interactions Pages 131-181 in: Plant-Microbe Interactions. Molecular and Genetic Perspectives. Volume III. T. Kosuge and E. W. Nester, eds., McGraw-Hill, New York.

Hardham, A. R., Gubler, F., Duniec, J., and Elliott, J. 1991. A review of methods for the production and use of monoclonal antibodies to study zoosporic plant pathogens. J. Microsc. 162:305-318.

Jarvis, M. C., Threlfall, D. R., and Friend, J. 1981. Potato cell wall polysaccharides: Degradation with enzymes from Phytophthora infestans. J. Exp. Bot. 32:1309-1319

Jolley, K. A., Feil, E. J., Chan, M.-S., and Maiden, M. C. J. 2001. Sequence type analysis and recombinational tests (START). Bioinformatics 17:1230-1231.

Kamoun, S., Hraber, P., Sobral, B., Nuss, D., and Govers, F. 1999. Initial assessment of gene diversity for the oomycete pathogen Phytophthora infestans based on expressed sequences. Fung. Genet. Biol. 28:94-106.

Ku, H.-M., Vision, T., Liu, J., and Tanksley, S. D. 2000. Comparing sequenced segments of the tomato and Arabidopsis genomes: Largescale duplication followed by selective gene loss creates a network of synteny. Proc. Natl. Acad. Sci. U.S.A. 97:9121-9126.

Leckie, F., Mattei, B., Capodicasa, C., Hemmings, A., Nuss, L., Aracri, B., De Lorenzo, G., and Cervone, F. 1999. The specificity of polygalacturonase-inhibiting protein (PGIP): A single amino acid substitution in the solvent-exposed $\beta$-strand/ $\beta$-turn region of the leucine-rich repeats (LRRs) confers a new recognition capability. EMBO (Eur. Mol. Biol. Organ.) J. 18:2352-2363.

Mao, Y., and Tyler, B. M. 1996. Cloning and sequence analysis of elicitin genes of Phytophthora sojae. Fung. Genet. Biol. 20:169-172.

Martel, M.-B., Létoublon, R., and Fèvre, M. 1996. Purification of endo polygalacturonases from Sclerotinia sclerotiorum: Multiplicity of the complex enzyme system. Curr. Microbiol. 33:243-248.

Martel, M.-B., Létoublon, R., and Fèvre, M. 1998. Purification and characterization of two endopolygalacturonases secreted during the early stages of the saprophytic growth of Sclerotinia sclerotiorum. FEMS (Fed. Eur. Microbiol. Soc.) Lett. 158:133-138.

Maynard Smith, J. 1992. Analyzing the structure of genes. J. Mol. Evol. 34:126-129.

Mendgen, K., and Deising, H. 1993. Infection structures of fungal plant pathogens - a cytological and physiological evaluation. New Phytol. 124:193-213.

Mendgen, K., Hahn, M., and Deising, H. 1996. Morphogenesis and mechanisms of penetration by plant pathogenic fungi. Annu. Rev. Phytopathol. 34:367-386.

Nei, M., and Gojobori, T. 1986. Simple methods for estimating the numbers of synonymous and nonsynonymous nucleotide substitutions. Mol. Biol. Evol. 3:418-426. 
Nei, M., and Hughes, A. L. 1992. Balanced polymorphism and evolution by the birth-and-death process in the MHC loci. Pages 27-38 in: Proceedings of the 11th International Histocompatibility Workshop and Conference, Vol. 2. K. Tsuji, M. Aizawa, and T. Sasazuki, eds. Oxford University Press, Oxford.

Nielsen, R., and Yang, Z. 1998. Likelihood models for detecting positively selected amino acid sites and applications to the HIV-1 envelope gene. Genetics 148:929-936.

Nielsen, H., Engelbrecht, J., Brunak, S., and von Heijne, G. 1997. Identification of prokaryotic and eukaryotic signal peptides and prediction of their cleavage sites. Protein Eng. 10:1-6.

Pagès, S., Heijne, W. H. M., Kester, H. C. M., Visser, J., and Benen, J. A. E. 2000. Subsite mapping of Aspergillus niger endopolygalacturonase II by site-directed mutagenesis. J. Biol. Chem. 275:29348-29353.

Panabières, F., Marais, A., Le Berre, J.-Y., Penot, I., Fournier, D., and Ricci, P. 1995. Characterization of a gene cluster of Phytophthora cryptogea which codes for elicitins, proteins inducing a hypersensitive-like response in tobacco. Mol. Plant-Microbe Interact. 8:996-1003.

Pařenicová, L., Benen, J. A. E., Kester, H. C. M., and Visser, J. 1998. pgaE encodes a fourth member of the endopolygalacturonase gene family from Aspergillus niger. Eur. J. Biochem. 251:72-80.

Pařenicová, L., Benen, J. A. E., Kester, H. C. M., and Visser, J. 2000a $p g a \mathrm{~A}$ and $p g a \mathrm{~B}$ encode two constitutively expressed endopolygalacturonases of Aspergillus niger. Biochem. J. 345:637-644.

Pařenicová, L., Kester, H. C. M., Benen, J. A. E., and Visser, J. 2000b. Characterization of a novel endopolygalacturonase from Aspergillus niger with unique kinetic properties. FEBS (Fed. Eur. Biochem. Soc.) Lett. 467:333-336.

Parniske, M., and Jones, J. D. G. 1999. Recombination between diverged clusters of the tomato $C f-9$ plant disease resistance gene family. Proc. Natl. Acad. Sci. U.S.A. 96:5850-5855.

Peitsch, M. C. 1995. Protein modeling by e-mail. Biotechnol. 13:658-660.

Peitsch, M. C. 1996. ProMod and Swiss-Model: Internet-based tools for automated comparative protein modelling. Biochem. Soc. Trans. 24:274-279.

Philippe, H., Germot, A., and Moreira, D. 2000. The new phylogeny of eukaryotes. Curr. Opin. Genet. Dev. 10:596-601.

Pickersgill, R., Smith, D., Worboys, K., and Jenkins, J. 1998. Crystal structure of polygalacturonase from Erwinia carotovora ssp. carotovora. J. Biol. Chem. 273:24660-24664.

Pieterse, C. M. J., Van West, P., Verbakel, H. M., Brassé, P. W. H. M., Van den Berg-Velthuis, G. C. M., and Govers, F. 1994. Structure and genomic organization of the ipiB and ipiO gene clusters of Phytophthora infestans. Gene 138:67-77.

Rogers, L. M., Kim, Y.-K., Guo, W. J., Gonzáles-Candelas, L., Li, D., and Kolattukudy, P. E. 2000. Requirement for either a host- or pectin-induced pectate lyase for infection of Pisum sativum by Nectria hematococca. Proc. Natl. Acad. Sci. U.S.A. 97:9813-9818.

Rudd, P. M., Elliott, T., Cresswell, P., Wilson, I. A., and Dwek, R. A. 2001. Glycosylation and the immune system. Science 291:2370-2376.

Sambrook, J., Fritsch, E. F., and Maniatis, T. 1989. Molecular Cloning: A Laboratory Manual. Cold Spring Harbor Laboratory Press, Cold Spring Harbor, NY, U.S.A.

Sanchez, L. M., Doke, N., Ban, Y., and Kawakita, K. 1994. Involvement of suppressor-glucans and plant epidermal cells in host-selective pathogenesis of Phytophthora capsici. J. Phytopathol. 140:153-164.

Sawyer, S. A. 1999. GENECONV: A computer package for the detection of gene conversion. Washington University Department of Mathematics, St. Louis.

Schumann, G. L. 1991. Plant Diseases: Their Biology and Social Impact American Phytopathological Society Press, St. Paul, MN, U.S.A.

Scott-Craig, J. S., Cheng, Y.-Q., Cervone, F., De Lorenzo, G., Pitkin, J. W., and Walton, J. D. 1998. Targeted mutants of Cochliobolus carbonum lacking the two major extracellular polygalacturonases. Appl. Environ. Microbiol. 64:1497-1503.

Sharrock, K. R., and Labavitch, J. M. 1994. Polygalacturonase inhibitors of Bartlett pear fruits: Differential effects on Botrytis cinerea polygalacturonase isozymes, and influence on products of fungal hydrolysis of pear cell walls and on ethylene induction in cell culture. Physiol. Mol. Plant Pathol. 45:305-319.

Shieh, M.-T., Brown, R. L., Whitehead, M. P., Cary, J. W., Cotty, P. J., Cleveland, T. E., and Dean, R. A. 1997. Molecular genetic evidence for the involvement of a specific polygalacturonase, P2c, in the invasion and spread of Aspergillus flavus in cotton bolls. Appl. Environ. Microbiol. 63:3548-3552.

Sogin, M. L., and Silberman, J. D. 1998. Evolution of the protists and protistan parasites from the perspective of molecular systemics. Int. J. Parasitol. 28:11-20.

Stotz, H. U., Contos, J. J. A., Powell, A. L. T., Bennett, A. B., and Labavitch, J. M. 1994. Structure and expression of an inhibitor of fun- gal polygalacturonases from tomato. Plant Mol. Biol. 25:607-617.

Stotz, H. U., Bishop, J. G., Bergmann, C. W., Koch, M., Albersheim, P., Darvill, A. G., and Labavitch, J. M. 2000. Identification of target amino acids that affect interactions of fungal polygalacturonases and their plant inhibitors. Physiol. Mol. Plant Pathol. 56:117-130.

Stratilová, E., Markovič, O., Škrovinová, D., Rexová-Benková, L., and Jörnvall, H. 1993. Pectinase Aspergillus sp. polygalacturonase: Multiplicity, divergence, and structural patterns linking fungal, bacterial, and plant polygalacturonases. J. Protein Chem. 12:15-22.

Stratilová, E., Mislovičová, D., Kačuráková, M., Machová, E., Kolarová, N. Markovič, O., and Jörnvall, H. 1998. The glycoprotein character of multiple forms of Aspergillus polygalacturonase. J. Protein Chem. 17:173-179.

Suykerbuyk, M. E. G., Kester, H. C. M., Schaap, P. J., Stam, H., Musters, W., and Visser, J. 1997. Cloning and characterization of two rhamnogalacturonan hydrolase genes from Aspergillus niger. Appl. Environ. Microbiol. 63:2507-2515.

Swofford, D. L. 1998. PAUP*: Phylogenetic analysis using parsimony. Sinauer, Sunderland, MA, U.S.A.

ten Have, A., Mulder, W., Visser, J., and van Kan, J. A. L. 1998. The endopolygalacturonase gene $B \operatorname{cpg} 1$ is required for full virulence of Botrytis cinerea. Mol. Plant-Microbe Interact. 11:1009-1016.

ten Have, A., Breuil, W. O., Wubben, J. P., Visser, J., and van Kan, J. A. L. 2001. Botrytis cinerea endopolygalacturonase genes are differentially expressed in various plant tissues. Fungal Genet. Biol. 33:97105.

Tenberge, K. B., Homann, V., Oeser, B., and Tudzynski, P. 1996. Structure and expression of two polygalacturonase genes of Claviceps purpurea oriented in tandem and cytological evidence for pectinolytic enzyme activity during infection of rye. Phytopathology 86:1084-1097.

Torki, M., Mandaron, P., Mache, R., and Falconet, D. 2000. Characterization of a ubiquitous expressed gene family encoding polygalacturonase in Arabidopsis thaliana. Gene 242:427-436.

Torto, T. A., Rauser, L., and Kamoun, S. 2002. The pipg 1 gene of the oomycete Phytophthora infestans encodes a fungal-like endopolygalacturonase. Curr. Genet. 40:385-390.

van der Cruyssen, G., de Meester, E., and Kamoen, O. 2001. Expression of polygalacturonases of Botrytis cinerea in vitro and in vivo. Meded. Fac. Landbouwwet. Rijksuniv. Gent 59:895-905.

van Santen, Y., Benen, J. A. E., Schröter, K.-H., Kalk, K. H., Armand, S., Visser, J., and Dijkstra, B. W. 1999. 1.68-Å crystal structure of endopolygalacturonase II from Aspergillus niger and identification of active site residues by site-directed mutagenesis. J. Biol. Chem. 274:30474-30480

Weerakoon, N. D., Roberts, J. K., Lehnen, L. P., Wilkinson, J. M Marshall, J. S., and Hardham, A. R. 1998. Isolation and characterization of the single $\beta$-tubulin gene in Phytophthora cinnamomi. Mycologia 90:85-95

Weiller, G. F. 1998. Phylogenetic profiles: A graphical method for detecting genetic recombinations in homologous sequences. Mol. Biol. Evol. 15:326-335.

Wubben, J. P., Mulder, W., ten Have, A., van Kan, J. A. L., and Visser, J. 1999. Cloning and partial characterization of endopolygalacturonase genes from Botrytis cinerea. Appl. Environ. Microbiol. 65:1596-1602.

Wubben, J. P., ten Have, A., van Kan, J. A. L., and Visser, J. 2000. Regulation of endopolygalacturonase gene expression in Botrytis cinerea by galacturonic acid, ambient $\mathrm{pH}$ and carbon catabolite repression. Curr. Genet. 37:152-157.

Wyss, D. F., and Wagner, G. 1996. The structural role of sugars in glycoproteins. Curr. Opin. Biotechnol. 7:409-416.

Yang, Z., and Bielawski, J. P. 2000. Statistical methods for detecting molecular adaptation. Trends Ecol. Evol. 15:496-503.

Yang, Z., and Nielsen, R. 2000. Estimating synonymous and nonsynonymous substitution rates under realistic evolutionary models. Mol. Biol. Evol. 17:32-43

Yang, Z., Nielsen, R., Goldman, N., and Pedersen, A.-M. K. 2000. Codon-substitution models for heterogeneous selection pressure at amino acid sites. Genetics 155:431-449.

Yao, C., Conway, W. S., and Sams, C. E. 1995. Purification and characterization of a polygalacturonase-inhibiting protein from apple fruit Phytopathology 85:1373-1377.

Yoshikawa, M., Tsukadaira, T., Masago, H., and Minoura, S. 1977. A non-pectolytic protein from Phytophthora capsici that macerates plant tissue. Physiol. Plant Pathol. 11:61-70.

\section{AUTHOR-RECOMMENDED INTERNET RESOURCE}

GENECONV Molecular Biology Computer Program, Washington University Department of Mathematics, St. Louis: http:// www. math.wustl.edu/ sawyer/geneconv 